\title{
ARBITRAGEM EM CONTRATOS FIRMADOS POR EMPRESAS ESTATAIS
}

\author{
Diogo de Figueiredo Moreira NETO* \\ marCoS JURUENA VILlELA SOUTO**
}

Contrato firmado por empresa estatal. O status constitucional das sociedades de economia mista no ordenamento brasileiro. Conteúdo econômico disponível. Cláusula compromissória de arbitragem inserta em contratos de sociedades de economia mista. Segurança juridica e boa fé objetiva como princípios aplicados aos contratos em que é parte a Administração Pública.

Cuida-se de examinar se um Contrato de Venda e Compra de Potência Assegurada, firmado entre uma autorizatária de produção independente de energia elétrica e uma sociedade de economia mista pode conter cláusula por força da qual qualquer controvérsia oriunda ou associada ao Contrato poderia ser solucionada por arbitragem.

1. A natureza jurídica do contrato de compra e venda de potência assegurada

\subsection{Contratos da Administração e contratos administrativos}

Cabe, desde logo, afirmar que a Lei ${ }^{\circ} 8.666 / 93$ não trata, apenas, dos contratos administrativos, cabendo, assim, que a primeira distinção a ser feita deva sê-lo entre contrato da Administração e contrato administrativo.

Com efeito, quando a Administração Pública figura em um dos pólos de uma relação contratual, não necessariamente está-se diante de um contrato administrativo. Conquanto a mera presença da Administração como parte caracterize o contrato da

* Titular de Direito Administrativo da Universidade Cândido Mendes. Procurador do Estado do Rio de Janeiro e advogado.

** Professor do Mestrado em Direito da Universidade Cândido Mendes. Procurador do Estado do Rio de Janeiro e advogado.

R. Dir. Adm., Rio de Janeiro. 236: 215-261, Abr./Jun. 2004 
Administração, a característica diferenciadora entre ambos os institutos está na existência das chamadas cláusulas exorbitantes' ${ }^{\prime}$, que outorgam poderes e prerrogativas de Direito Público, inadmissíveis em um contrato exclusivamente regido pelo Direito Privado. Nestes, o regime jurídico é, por isso e em regra, de Direito Público, aplicando-se supletivamente os princípios da Teoria Geral dos Contratos e as disposições do Direito Privado, tal qual hoje disciplina, na ordem jurídica brasileira, o art. 54, da Lei ${ }^{\circ} 8.666 / 93$.

Mas, distintamente, é sempre possível que em certos contratos a Administração Pública ostente posição jurídica de igualdade em relação à contraparte privada, despida das prerrogativas inerentes aos referidos contratos administrativos, daí serem assim chamados de contratos privados da Administração.

Para esses, aplica-se, portanto, ao revés, o regime jurídico dos contratos privados, não obstante imponha-se a observância de algumas formalidades indispensáveis e inerentes a qualquer contrato que envolva a Administração Pública.

Tanto é assim, que a norma explícita quais são os dispositivos da Lei $n^{\circ} 8.666 / 93$ que se aplicam "no que couber" a estes contratos, o que vale dizer que somente incidem regras que não thes desnaturem a essência dos ajustes privados.

Esta premissa é fundamental, especialmente, em relação à aplicação do art. 58, que trata das cláusulas exorbitantes; este é incompatível, frise-se, quase sempre, com a natureza predominantemente privada dos contratos nos quais a alteração unilateral, por exemplo, pode ensejar o total rompimento do equilibrio contratual a ponto de inviabilizá-lo e, com isso, afastando a incidência do art. 54 da Lei $n^{\circ} 8.666 / 93$ que remete a matéria à teoria geral dos contratos.

Dentre as formalidades de direito público, cite-se a regra por força da qual os contratos da Administração devem conter cláusula que estabeleça o foro da Administração como o competente para apreciar controvérsias, formalidade essa que não pode e não deve ser entendida como uma obrigatoriedade substantiva de que se discuta toda e qualquer questão em juízo, e não só porque se confundem as distintas obrigações em sua natureza, como porque tal confusão conduziria ao absurdo de se impedir qualquer negociação amigável.

1 MOREIRA NETO, Diogo de Figueiredo: "(...) uma vez que ocorra uma redefinição do interesse público, durante a vigência do contrato, que o afete em suas cláusulas, 'a imperatividade, latente como de resto, en qualquer aluação do Estado, poderá eventualmente emergir, para determinar uma alteração ou, até, a extinção do contrato', por ato unilateral de vontade da Administração. Realmente, se o interesse publico assim o exigir, 'a imperatividade natural do Estado' - que nāo se manifesta na constituição do vínculo - exsurgirá, 'para ditar sua modificação ou até a sua extinção. seja pela alteração. seja pela supressão do objeto indisponível', que contém aquele interesse público." In. Curso de Direito Administrativo. 13. ed. Rio de Janeiro: Forense, 2003, p. 164. Sobre o tema, leia-se também: SOUTO, Marcos Juruena Villela. Licitações \& Contratos Administrativos. 3. ed. Rio de Janciro: Esplanada, 2001, p. 309. MELLO, Celso Antônio Bandeira de. Curso de Direito Administrativo. 14. ed. Sūo Paulo: Malheiros, 2002, p. 559. JUSTEN FILHO, Marçal. Comentários à Lei de Licitações e Contratos Administrativos. 9. ed. São Paulo: Dialética, p. 458. FIGUEIREDO, Lúcia Valle. Curso de Direito Administrativo. 6. ed. São Paulo: Malheiros, 2003, p. 499. E, por todos: MEIRELLES, Hely Lopes. Direito Administrativo Brasileiro. 24. ed. São Paulo: Malheiros, 1999, pp. 195 e 196. 
Portanto, o que faz sentido dessumir do dispositivo do art. $55, \S 2^{\circ}$ é que, em sendo inevitável, as partes podem ir ao Judiciário, indicando-se, para tanto, o foro, mas não sem que se thes permita estabelecer mecanismos de solução de controvérsias, sob pena de faltar-lhes, em eventual ingresso prematuro em juizo, o interesse de agir.

CAIO TÁCITO², em concordância, afirma que:

"Na medida em que é permitido à Administração Pública, em seus diversos órgãos e organizações, pactuar relações com terceiros, especialmente mediante a estipulação de cláusulas financeiras, a solução amigável é fórmula substitutiva do dever primário de cumprimento da obrigação assumida.

Assim como é lícita, nos termos do contrato, a execução espontânea da obrigação, a negociação - e, por via de consequiência, a convenção da arbitragem será meio adequado de tornar efetivo o cumprimento obrigacional quando compatível com à disponibilidade de bens.

Em suma, nem todos os contratos administrativos envolvem, necessariamente, direitos indisponíveis da Administração.

Certamente, haverá casos em que a prestação assumida pelo Estado possa corresponder a interesses públicos de uso de bens públicos ou a fruição de vantagens que não se compadecem com a disponibilidade ou a alienação do patrimônio estatal.

Quanto a estes, somente o Poder Judiciário poderá, no exercício de suas prerrogativas, impor à Administração deveres ou obrigações de fazer ou não fazer, de permitir ou de autorizar.

Todavia, quando se trata tão-somente de cláusulas pelas quais a Administração está submetida a uma contraprestação financeira. não faz sentido ampliar o conceito de indisponibilidade à obrigação de pagar vinculada à obra ou serviço executado ou ao benefício auferido pela Administração em virtude da prestação regular do outro contratante.

A convenção da arbitragem será, em tais casos, caminho aberto a que, pelo acordo de vontades, se possa alcançar a plena eficácia da relação contratual.

Mas ainda se compatibiliza o juízo arbitrai com atos de gestão de empresa estatal que se dedique à exploração de atividade econômica na qual, nos termos da Constituição de 1988 , art. $173, \S 1^{\circ}$, prevalece o regime jurídico das empresas privadas, (n/grifo).

2 TÁCITO, Caio. Temas de direito püblico. Rio de Janeiro: Renovar, 2002, v. 3, pp. 87 e 88. 
E acrescenta o ilustre Mestre, dando relevo ao sentido prático subjacente a qualquer interpretação pautada pela razoabilidade ${ }^{3}$ :

"O acordo conducente ao procedimento arbitrai, superando a delonga do rito judicial, favorece a celeridade na superação de litígios em benefício da dinâmica própria das relações econômicas, que o Estado venha a assumir como imperativo do interesse coletivo." (n/grifo)

Não há, pois, mesmo no âmbito da Lei $n^{\circ} 8.666 / 93$, qualquer impedimento, que se possa retirar do seu art. $55, \S 2^{\circ}$, à utilização da arbitragem. Frise-se, no entanto, que a orientação firmada é a da inaplicabilidade da Lei $n^{\circ} 8.666 / 93$ às estatais, 0 que vem em reforço dessa conclusão.

\subsection{O regime jurídico das empresas estatais}

Os traços marcantes das sociedades de economia mista ou empresas públicas seriam a autorização para sua criação em lei para desempenhar uma atividade economica ligada aos fins da entidade controladora.

Ainda por força da Constituição, no caso de estatais distribuidoras de energia, no entanto, mister se faz lembrar que não representam uma descentralização de função estadual, posto que a competência para a prestação dos serviços de energia elétrica é da União, consoante o disposto nos arts. 21, XII, b, e 22, IV da Constituição Federal. No art. 173, $\S 1^{\circ}$, II, da Constituição ${ }^{4}$, submetem-se elas ao regime próprio das empresas privadas, o que permite inferir que podem, em igual medida, celebrar contratos nos moldes adotados no setor privado, observados apenas os princípios que orientam o funcionamento da Administração Pública.

Essas entidades se submetem a um regime jurídico hibrido apenas na medida em que sofrem, também, o impacto de normas de direito público, voltadas para o exercício do poder do acionista controlador - que age na direção da sociedade como qualquer sócio controlador - bem como normas públicas sobre físcalização da gestão. Isto ocorre por força de uma opção discricionária de descentralização do Poder político ao criar, conforme o permissivo constitucional referido, uma entidade com personalidade jurídica própria de direito privado para atuar em um determinado segmento econômico ou para prestar indiretamente um serviço público.

3 TÁCITO, Caio. Temas de dircito püblico. Rio de Janeiro: Renovar, 2002, v. 3, p.88

4 "Art. 173. Ressalvados os casos previstos nesta Constituição, a explorą̧ão direta de atividade econômica pelo Estado só será permitida quando necessária aos imperativos da segurança nacional ou a relevante interesse coletivo, conforme definidos em lei. $\$ 1^{\circ}$ A lei estabelecerá o estatuto jurídico da empresa pública. da sociedade de economia mista e de suas subsidiárias que explorem atividade econômica de produção ou comercializą̧ão de bens ou de prestação de serviços, dispondo sobre: I - sua funç̧ão social e formas de fiscalização pelo Estudo e pela sociedade; II - a sujeição ao regime juridico próprio das empresas privadas, inclusive quanto aos dircitos e obrigações civis, comerciais, trabalhistas e tributários." (n/grifo) 
Assim, devem tais entidades, dentre outras regras específicas que lhes alcançam, observância aos princípios constitucionais da legalidade, moralidade, impessoalidade, publicidade e eficiência, mas, com igual eficácia normativa ${ }^{5}$, sujeitam-se ao princípio constitucional da livre concorrência ${ }^{6}$, o que lhes desautoriza o uso de prerrogativas de Estado ou cláusulas exorbitantes em temas econômicos de seus contratos.

Há que se esclarecer um freqüente equívoco que é o de confundir contratos da Administração com contratos administrativos. Na verdade, os contratos celebrados por empresas estatais não devem ser considerados contratos administrativos, isso porque, nos termos da $\mathrm{CF}$, art. $173, \S \S 1^{\circ}$, II e $2^{\circ}$, elas realizam negócios jurídicos despidas da supremacia do poder de império inerente aos entes públicos.

Tal fenômeno decorre, pois, da própria personalidade jurídica de direito privado das sociedades de economia mista e empresas públicas, que lhes impõe regime distinto das demais entidades da Administração Pública.

\subsection{O regime jurídico do contrato e a previsão de contratação direta de} fornecimento de energia

A Lei de Licitações e Contratos Administrativos, Lei $\mathrm{n}^{\circ}$ 8.666, de 21 de junho de 1993, dispõe, em seu art. 24, XXII, que é dispensável a licitação:

"XXII - na 'contratação de fornecimento' ou suprimento de 'energia elétrica e gás natural com concessionário', permissionário ou autorizado, segundo as normas da legislação específica; (n/grifo)

A norma tem o nítido propósito de viabilizar a agilidade das negociações, incompatível com o formalismo inerente ao procedimento.

Tal provisão integra-se a um contexto de estímulos ao surgimento de novos investimentos (privados) no setor de geração de eletricidade, dada a incapacidade financeira de o Poder Público fazê-lo em tempos de déficit orçamentário.

São, assim, previstas as figuras do produtor independente e do autoprodutor de energia. O primeiro produz energia como mercadoria que serve de insumo às concessionárias de serviço público; o segundo, como o próprio nome sugere, a produz para seu próprio consumo. Não são, nem um nem outro, prestadores de serviços públicos e suas relações, com seus respectivos clientes e fornecedores, são de direito privado, ainda que sua titulação, suas instalações e sua mercadoria sejam submetidas à regulação, tendo em vista a necessidade de "segurança" do destinatário.

Até mesmo o preço praticado pode se submeter a algum tipo de regulação, dado o seu impacto sobre a modicidade das tarifas a serem praticadas pelo concessionário adquirente.

5 Art. 37, caput, CF.

6 Art. 170, IV, CF. 
Nenhuma dessas regulações específicas, no entanto, modifica o regime jurídico desses contratos, que, frise-se, é de direito privado.

Um desses clientes do fornecimento da energia produzida pela autorizatária de produção independente de energia é uma sociedade de economia mista, que, como dito, é concessionária de um serviço público federal, submetendo-se, portanto, por força dos arts. 22, 23, 24 e 25 da Lei $n^{\circ} 9.074 / 95$, a um contrato de concessão firmado nos termos da Lei ${ }^{\circ} 8.987 / 95$, um diploma que, sublinhe-se incidentalmente, em seu art. 23, XV, já submete a sociedade de economia mista à arbitragem, inclusive com a Administração Pública concedente (o que se verá adiante).

E como concessionária, nos termos da Lei $n^{\circ} 8.987 / 95$, importa, por ora, frisar que a sociedade de economia mista firma contratos de direito privado, na forma do art $25, \S 2^{\circ}$ da Lei $n^{\circ} 8.987 / 95$, o que só reafirma, na hipótese, o disposto no art. $173, \S 1^{\circ}$, II, da Constituição.

E mais, afirma o dispositivo acima (o que se verá adiante), que não se estabelece qualquer relação entre os contratados da concessionária (seus fornecedores de insumos) e o poder concedente (no caso, a ANEEL), o que ainda mais reforça a natureza privada e comercial dessas relações.

Assim, no contrato privado celebrado entre a concessionária e terceiros produtores, a participaşāo da ANEEL será apenas a de fiscalizar a atividade e as instalações; jamais as questões comerciais que se travam entre o contratante e seus fornecedores.

\section{O papel da ANEEL nos contratos de compra e venda de energia}

A Lei $\mathrm{n}^{\circ} 9.074$, de 7 de julho de 1995 , que estabelece normas para outorgas e prorrogações das concessões e permissões de serviços públicos dispõe, em seu art. 11, sobre a figura do produtor independente de energia, que, como dito, produz energia para venda, uma titulação que depende de ato do Poder Concedente.

Recorde-se que a Lei $n^{\circ}$ 9.427, de 26 de dezembro de 1996, instituiu a Agência Nacional de Energia Elétrica - ANEEL, atribuindo-lhe o poder concedente dessa atividade econômica setorial e disciplinando-lhe o regime das concessões de serviços públicos de energia elétrica. $\mathrm{O}$ art. $3^{\circ}$ atribui-lhe o dever de controlar, regular e fiscalizar os serviços e instalações. Nessa linha, e tendo em vista, em especial, o disposto no art. 11 da Lei $n^{\circ} 9.074 / 95$, compete à ANEEL atribuir os títulos jurídicos de ingresso no segmento econômico da exploração da energia elétrica, por meio de concessão, permissão e autorização, o que faz mediante processo de exame das condições pessoais de cada interessado e, quando o caso, por escolhas em processo licitatório (no qual tais condições são apreciadas na fase de habilitação).

No âmbito da produção independente de energia térmica (que dispensa o uso do bem público - o potencial de energia elétrica), a licitação é inexigível, bastando aos interessados comprovar sua aptidão de fornecer um produto seguro para obter a autorização.

O Decreto $n^{\circ} 2.003$, de 10 de setembro de 1996, que regulamenta a produção de energia elétrica por produtor independente e por autoprodutor, dispõe sobre a 
necessidade de concessão ou autorização para efeitos de produção de energia elétrica tanto para os autoprodutores quanto para os produtores independentes:

“Art. $1^{\circ}$ A produção de energia elétrica, por produtor independente e por autoprodutor, depende de concessão ou autorização, que serão outorgadas na forma da legislação em vigor e deste Decreto."

Art. $2^{\circ}$ Para fins do disposto neste Decreto, considera-se:

I - Produtor Independente de Energia Elétrica, a pessoa jurídica ou empresas reunidas em consórcio que recebam concessão ou autorização para produzir energia elétrica destinada ao comércio de toda ou parte da energia produzida, por sua conta e risco;

II - Autoprodutor de Energia Elétrica, a pessoa física ou jurídica ou empresas reunidas em consórcio que recebam concessão ou autorização para produzir energia elétrica destinada ao seu uso exclusivo.

\section{(...)}

Art. $4^{\circ}$ Dependem de autorização:

I - a implantação de usina termelétríca de potência superior a $5.000 \mathrm{~kW}$, destinada a autoprodutor e a produtor independente;" (n/grifo).

O produtor independente tem na geração de energia a sua mercadoria - arcando, assim, com todos os riscos inerentes à atividade empresarial - cujo adquirente pode ser, exemplificativamente, tanto o concessionário de serviço público ou o comercializador, como o próprio usuário final.

O Decreto $\mathrm{n}^{\circ} 2.003 / 96$, em seus arts. 23 a 26, dispõe, especificamente, sobre o produtor independente:

"Art. 23. O produtor independente poderá comercializar a potência e/ou energia com:

I - concessionário ou permissionário de serviço público de energia elétrica;

II - consumidores de energia elétrica nas condições estabelecidas nos artigos 15 e 16 da Lei $n^{\circ} 9.074$, de 1995 ;

III - consumidores de energia elétrica integrantes de complexo industrial ou comercial, aos quais forneça vapor ou outro insumo oriundo de processo de cogeração;

IV - conjunto de consumidores de energia elétrica, independentemente de tensão e carga, nas condições previamente ajustadas com o concessionário local de distribuição;

$\mathrm{V}$ - qualquer consumidor que demonstre ao poder concedente não ter o concessionário local the assegurado o fornecimento no prazo de até 180 dias, contado da respectiva solicitação.

Parágrafo único. A comercialização de energia elétrica nas hipóteses dos incisos I, IV e V deste artigo deverá ser feita a preços sujeitos aos critérios gerais fixados pelo poder concedente". 
Como dito acima, tais contratos se submetem à regulação da ANEEL, conforme se vê no art. 24 do Decreto $n^{\circ} 2.003 / 96$ :

"Art. 24. Os contratos de comercialização de energia elétrica celebrados entre o produtor independente e o concessionário ou permissionário de serviço público de energia elétrica deverão ser submetidos por estes a homologação do órgão regulador e fiscalizador do poder concedente". (n/grifo)

Entretanto, tal fiscalização não poderá exceder aquilo que se insere na competência regulatória da ANEEL, a saber, as atividades e as instalações (art. $3^{\circ}$ da Lei $n^{\circ}$ 9.427/96), falecendo à ANEEL qualquer legitimidade para examinar matérias negociais entre produtor independente e concessionária que não interfiram com a adequação do serviço (a saber, modicidade, segurança, regularidade, atualidade e cortesia). Assim, pois, a previsão de arbitragem num contexto de direito privado não é tema sujeito à apreciação da ANEEL, que, como qualquer ente público, somente atua secundam legis.

Aliás, é o que se lê na própria Lei $n^{\circ}$ 9.427, de 26 de dezembro de 1996:

"Art. 25. No caso de concessão ou autorização para 'produção independente de energia elétrica', o contrato ou ato autorizativo definirá as condições em que o produtor independente poderá realizar a 'comercialização de energia elétrica produzida e da que vier a adquirir, observado o limite de potência autorizada', para atender aos contratos celebrados, inclusive na hipótese de interrupção da geração de sua usina em virtude de determinação dos órgãos responsáveis pela operação otimizada do sistema elétrico". (n/grifo)

A Resolução ANEEL $n^{\circ} 112$, de 18 de maio de 1999, que estabelece os requisitos necessários à obtenção de Registro ou Autorização para a implantação, ampliação ou repotenciação de centrais geradoras termelétricas, eólicas e de outras fontes alternativas de energia, dispõe:

"Art. $1^{\circ}$ Estabelecer os requisitos necessários à obtenção de Registro ou Autorização, junto à Agência Nacional de Energia Elétrica - ANEEL, para a implantação, ampliação ou repotenciação de centrais geradoras termelétricas, eólicas e de outras fontes alternativas de energia.

Art. $2^{\circ} \mathrm{O}$ disposto nesta Resolução aplica-se a:

(...)

II - pessoa física, 'pessoa jurídica ou empresas reunidas em consórcio interessadas em produzir energia elétrica destinada ao seu uso exclusivo';" (n/grifo)

Assim, o objetivo da homologação é, tão-somente, o de compatibilizar o contrato de comercialização de energia pelo produtor independente com o ato que the 
atribuiu tal direito e fixou-lhe as condições de atuação. Mais não pode haver, por representar invasão indevida nos negócios empresariais, com vulneração dos princípios constitucionais da livre iniciativa e da autonomia da vontade, como se verá adiante.

\section{Abordagem principiológica do juizo arbitral}

Ao firmarem o contrato de comercialização da energia gerada a partir da produção independente, as partes ajustaram entre si mecanismo célere e especializado de solução de suas controvérsias comerciais. Tal preocupação com a agilidade e a especialização vem desde a assinatura do protocolo de intenções, que deu origem à decisão de investimento no Brasil e, em especial, no Estado do Paraná.

Frise-se que tal investimento deu aplicabilidade ao conceito de produção independente de energia - como adminículo à incapacidade financeira do Estado de promover a geração de modo a acompanhar a necessidade de aumento da quantidade e de qualidade de energia.

Como tal, o produtor independente, na condição de parceiro do Poder Público, assumiu riscos, inclusive contraindo financiamentos externos, na presunção de que as obrigações assumidas seriam respeitadas e, no caso de eventual conflito, prontamente solucionadas por meios previstos no contrato, sem necessidade de se socorrerem dos trâmites judiciários.

É óbvio que a sociedade de economia mista, ao frustrar tal expectativa, de pura natureza privada e negocial, traz graves conseqüências jurídicas, políticas e econômicas, que deveriam ter sido por ela prudentemente consideradas, e não apenas para a autorizatária, no âmbito do contrato firmado, como, no plano internacional, para o próprio País, na sua legítima pretensão de atrair investidores em tempos de déficit orçamentário (o que a Lei de Responsabilidade Fiscal busca corrigir).

Esse comportamento, além de desastroso na perspectiva político-econômica, no âmbito jurídico, viola inúmeros princípios consagrados no ordenamento jurídico brasileiro, como se passa a expor:

\subsection{A arbitragem e o princípio da efetividade da Justiça}

A solução dos conflitos de interesses passou da autotutela à prestação jurisdicional como meio de promover segurança e justiça e de lograr a paz social. Nesse último estágio, o Estado assumiu o monopólio da justiça, uma exclusividade que, embora adequada aos modelos de concentração de poder então vigentes, veio a se tornar incompatível diante de novas realidades que, com a evolução tecnológica e cultural e a revolução das comunicações experimentadas no século passado, apresentam um irreprimível incremento e complexidade de necessidades coletivas e uma explosiva gama de relações sobre elas travadas.

Nessa realidade, não há como o Estado pretender assumir, sozinho, a titularidade, a gestão ou a responsabilidade sobre todos os interesses públicos e muito 
menos, manter o monopólio da justiça, como uma atitude de tutela da sociedade, a que deve servir e não dirigir.

O público, por ser de todos e não do Estado, daí a clássica distinção entre interesses públicos primários (da sociedade) e derivados (da máquina estatal), não afasta a sociedade, ainda porque é ela a sua última e soberana titular.

Ora, é ressabido que, nas condições atuais, o velho sistema monopolístico de distribuição de justiça provoca um inevitável e crescente acúmulo de pendências, que termina por submeter a alto risco a própria efetividade e a eficiência estatal no exercício da jurisdição, o que vem a ser, em última análise, a falência de sua própria capacidade de bem produzir justiça.

Assim, não obstante a tentativa, que é quase sempre alvitrada, para manter um obsoleto monopólio da justiça (que não se confunde com o monopólio da jurisdição - este, inerente ao próprio conceito de Estado), de resolver essa situação com o mero aumento da estrutura judiciária (cartórios, juízos, orçamento, modificaçōes na legislação processual e informatização da justiça), tornou-se indispensável nos Estados contemporâneos a adoção de fórmulas adicionais de solução de conflitos, em especial, à revitalização dos sistemas extrajudiciais, com destaque, no caso, para a arbitragem, o que Mauro Cappeletti denominou de terceira onda do movimento universal de acesso à justiça. ${ }^{\text {? }}$

Nesse passo e alinhando o Brasil com as novas tendências do Direito contemporâneo, o advento da Lei ${ }^{\circ} 9.703$, de 23 de setembro de 1996, trouxe a revitalização e a promoção desse instituto, já conhecido e aplicado desde o Decreto $n^{\circ} 737$, de 25 de novembro de 1850 , que previa a utilização da arbitragem na solução de conflitos entre comerciantes ${ }^{8}$.

Pouco depois de editada essa Lei, em 1997, se teve a oportunidade de analisá-la bem como a evolução conceptual que ditou a sua adoção no Direito brasileiro, em artigo que posteriormente foi incluido na coletânea denominada Mutações clo Direito Administrativo ${ }^{9}$, aqui mencionado porquanto suas posições doutrinárias foram então e continuam as mesmas no sentido aqui exposto. ${ }^{10}$

7 "Terceira onda" foi expressão usada pelo ilustre jurista no celebrado Relatório de Abertura do Simpósio Jurídico W. G. HART. sobre Justiça Civil e suas Alternativas, realizado em Londres, no Instituto of Legal Advanced Studies, em 7 a 9 de julho de 1992, com tradução de MOREIRA, José Carlos Barbosa, publicada no Volume 326, abril/maio/junho de 1994, da Revista Forense.

8 Embora a previsão de obrigatoriedade tenha sido revogada pela Lei $n^{\circ} 1.350$, de 14.09.1866, a arbitragem voluntária foi mantida e citada no Código Civil de 1916 (arts. 1.037 a 1.048), bem como no antigo Código de Processo Civil (arts. 1.03! a 1.046); este, ao ser remodelado em 1973 , estabeleceu a intervenção obrigatória do Poder Judiciário até o advento da citada Lei ${ }^{\circ}$ 9.307/96. 9 MOREIRA NETO, Diogo de Figueiredo. Mutações do Direito Administrativo. Artigo denominado Arbitragem nos Contratos Administrativos. 2. ed. Rio de Janeiro: Renovar, 2001, p. 221 a 235. 10 Quanto à visão juspolítica do fenômeno da terceira onda, foi afirmado então: "Foi necessário, portanto, mais de meio século de evolução juspolítica para que se viesse a lograr a superação da adoração hegeliana do Estado, dos preconceitos ideológicos das extremas esquerda e direita e da crença, um tanto ingênua, no valor absoluto das formas, e se restabelecesse o respeito à liberdade de buscar a justiça como exercício do consenso..." 
Voltando ao Diploma legal, uma importante inovação foi ter conferido à cláusula arbitral dos contratos os mesmos efeitos do compromisso arbitral para a instauração do juízo de arbitragem e dispensado a necessidade de homologação, pelo Poder Judiciário, do laudo arbitrai, reconhecendo, assim, autonomia à decisão arbitral. STJ ${ }^{11}$ :

Neste contexto, confira-se as palavras da Ministra Nancy Andrighi do Egrégio $"(\ldots)$

I- O tema em questão é muito novo em nossa jurisprudência e esparsos são os doutrinadores que se destinam ao seu estudo. 'A arbitragem não caracteriza renúncia ao exercício do direito de ação e sim uma das formas de se solucionar as controvérsias sem precisar da atuação do Poder Judiciário'. Não se trata de impedir o acesso ao Judiciário, como vem sendo fundamentado por alguns que entendem que a cláusula compromissória fere o art. $5^{\circ}, X X X V$, da $C F$ de 88 , e sim uma disponibilidade que tem os interessados de verem suas questões sendo dirimidas com maior celeridade, presteza e com menos entraves burocráticos (...)" (n/grifo)

Isso, além de realinhar o País com os sistemas jurídicos mais modernos, o que por si só apresenta inumeráveis vantagens práticas, em muito viabiliza ao Estado promover a paz social, por meio da solução dos conflitos, sem impacto nos deficitários orçamentos, sem a morosidade decorrente do excesso de feitos e com maior conhecimento técnico dos árbitros julgadores sobre assuntos empresariais do mais alto vulto e complexidade.

Não há, pois, renúncia à jurisdição, como, aliás, já fartamente reconhecido na jurisprudência citada ao longo deste estudo.

\subsection{A arbitragem e os princípios republicano e da vedação de retrocesso}

A rapidez, a economia, a redução de formalismos e, em muitas vezes, a maior legitimidade dos árbitros, aliadas ao dever de sigilo têm sido relevantes argumentos em favor da opção pela arbitragem.

Isso acaba por reduzir o risco e o custo das transações, atuando per se como um fator de fomento econômico, atraindo novos investimentos, que alavancam o desenvolvimento nacional, um dos objetivos da República que conduzem à busca do pleno emprego, à redução das desigualdades regionais, à erradicação da pobreza e, por consequiência, ao mais relevante de todos, qual seja, a dignidade da pessoa humana.

11 BRASIL. Superior Tribunal de Justiça. Recurso Especial n 450.881 - DF (2002/0079342-1). Relator: Ministro Castro Filho. Recorrente: Americel S/A, Recorrido: Compushopping Informática Ltda. - microempresa e outros. 
Ora, o direito ao desenvolvimento é daqueles que integram a quarta geração da revolução social e, portanto, se incorpora ao patrimônio jurídico dos administrados, sendo vedado o retrocesso econômico e social já alcançado (que teria o efeito de verdadeira expropriação do direito) - no caso, o direito a decisões céleres e especializadas e à existência de opções de jurisdição (no caso de interesses disponíveis).

Como dito, a negativa de aplicar a arbitragem como pactuada e, já aceita no caso concreto, opera efeitos contrários aos objetivos da República, consagrados no art. $3^{\circ}, \mathrm{CF}$, posto que afugenta os investidores num momento em que o deficit fiscal força sua busca.

\subsection{A arbitragem e o princípio da segurança jurídica}

Negar o avanço da revitalização da arbitragem, mais do que um retrocesso, é atentar contra o mega-princípio da segurança jurídica, que agasalha um dos maiores, senão o maior, valor buscado pelo direito positivo, o que também concorre para assustar os possíveis investidores por motivo da quebra da confiabilidade na preservação das "regras do jogo".

Sobre a questão da segurança jurídica, o Egrégio STJ já se manifestara pela pena do Ministro Gueiros Leite ${ }^{12}$ :

$"(\ldots)$

2. Esses contratos tem por fim eliminar as incertezas jurídicas, de modo que os figurantes se submetem, a respeito do direito, pretensão, ação ou excę̧ão, a decisão dos árbitros, aplicando-se aos mesmos a regra do art. 244, do CPC, se a finalidade for atingida.

(...)" (n/grifo)

Nunca é demais lembrar que, em matéria de ordenamento econômico, esse mega-princípio da segurança jurídica é, sem dúvida, dos mais relevantes, posto que, relacionado à confiança do investidor, lida, diretamente, com a boa fé que deve sempre reinar entre as partes que se relacionam com vistas à consecução de um objetivo comum. Isto mais se reforça justamente quando uma das partes é uma entidade da Administração Pública, da qual se espera enfaticamente o respeito ao cidadão e o atendimento do princípio da moralidade administrativa.

\subsection{A arbitragem e o princípio da autonomia da vontade}

Não há na legislação imposição de uso da arbitragem; seu emprego decorre da própria manifestação de vontade das partes; até porque, o próprio direito de ação é uma faculdade.

12 BRASIL. Superior Tribunal de Justiça. Recurso Especial n ${ }^{\circ} 616-R J$ (198900098535). Relator: Cláudio Santos. Órgão Julgador: TERCEIRA TURMA, Data da decisão: 24.04.1990, Fonte: DJ DATA: 13.08.1990 PÁGINA: 7647 RSTJ VOL.: 00037 PÁGINA: 263. 
Segundo a Lei em vigor, somente se submetem ao juízo arbitrai os conflitos que versem sobre direitos patrimoniais disponiveis ${ }^{13}$, mediante convenção de arbitragem, abrangendo as modalidades da cláusula compromissória e do compromisso arbitral (art. $3^{\circ}$, Lei ${ }^{\circ} 9.307 / 96$ ), assim caracterizadas: "A cláusula compromissória é a convenção pela qual as partes em um contrato comprometem-se a submeter à arbitragem os litígios que possam vir a surgir, relativamente a tal contrato" (art. $4^{\circ}$, caput, Lei $n^{\circ} 9.307 / 96$ ). Já o compromisso arbitral é a convenção por meio da qual as partes submetem um litígio à arbitragem de uma ou mais pessoas, podendo ser judicial ou extrajudicial (art. $9^{\circ}$, caput, Lei $\mathrm{n}^{\circ}$ 9.307/96).

$\mathrm{Na}$ lição de José Maria Rossani GARCEZ ${ }^{14}$ :

'A arbitragem decorre da vontade expressa pelas partes na convenção arbitral', que é gênero, da qual são espécies a 'cláusula compromissória' (introduzida nos contratos 'para submeter qualquer questão contratual futura a este método') e o 'compromisso arbitral' (termo que 'detalha a arbitragem após surgido o conflito', definindo seus limites, discriminando os dados pessoais dos árbitros escolhidos, o lugar da arbitragem e outros elementos necessários).

\section{(...)}

A existência de uma cláusula compromissória válida é suficiente para justificar a prejudicial de exclusão da via judicial a ser alegada pela outra parte caso uma delas se 'esqueça' e inobstante o particular da existência da cláusula compromissória, resolva ingressar em juizo. Este conceito já existe refletido em muitas decisões judiciais, a que os interessados poderão ter acesso ao consultar repertórios jurisprudenciais disponiveis". (n/grifo)

Neste diapasão, o Egrégio Tribunal Regional do Trabalho - TRT da $2^{\text {a }}$ Região ${ }^{15}$ assim julgou:

$$
\text { “(..) }
$$

13 No artigo Arbitragem nos Contratos Administrativos, inserido na obra Mutações do Direito Administrativo. 2. ed. (Rio de Janeiro: Renovar, 2001, p. 228), após o exame de alguns conceitos de indisponibilidade administrativa de interesses, oferece-se a seguinte conclusão: "São dispontveis... todos os interesses e os direitos deles derivados que tenham expressäo patrimonial. Ou seja, que possam ser quantificados monetariamente e estejam no comércio e que, são, por esse motivo. e normalmente, objeto de contratação que vise a dotar a Administraçāo ou seus delegados, dos meios instrumentais de modo a que estejam em condições de satisfazer os interesses finalísticos que justificam o próprio Estado."

14 GARCEZ, José Maria Rossani. Técnicas de Negociação - Resolução Alternativa de Conflitos: ADRS. Mediação, Conciliação e Arbitragem. Rio de Janeiro: Lumen Júris, 2002, p. 85 e 86.

15 BRASIL. Tribunal Regional Federal 2* Região. RO 2001.041.5240. Órgão Julgador: Sexta Turma. Julgamento: 05.03.2002. Relator: Juiz Altair Berty Martinez. 
A Lei $8.630 / 93$, art. 23 , também a instituiu e, no $\S 2^{\circ}$ do mesmo dispositivo, estabeleceu que, firmado o compromisso arbitral, não haverá desistência. Entretanto, essa disposição somente pode ser interpretada em sintonia com a Lei de Arbitragem, art. $4^{\circ}, \S 2^{\circ}$, segundo o qual "somente haverá eficácia da cláusula compromissória se o aderente tomar a iniciativa de instituir a arbitragem ou concordar, expressamente, com sua instituição, desde que por escrito em documento anexo ou em negrito, com assinatura e visto especialmente para essa cláusula, requisitos indispensáveis asseguradores da livre manifestação da vontade da parte aderente ao contrato" imposto pelo mais forte, porque entre nós, a arbitragem é facultativa e, se não fosse, seria inconstitucional lei dispondo diferentemente. $\left(C F\right.$, art. $\left.5^{\circ}, X X X V\right)(\ldots)^{\prime \prime}$ (n/grifo)

O Colendo Tribunal de Justiça do Estado do Rio de Janeiro também já se manifestou, pelo voto do Desembargador Ronald Valladares ${ }^{16}$ :

“(..)

'Existência de cláusula de compromisso arbitral no pacto. Desconsideração da cláusula, aceitando-se o processamento da lide perante a Justiça Comum Estadual, onde ação foi proposta. Inconformação da demandada, empresa sediada na Alemanha. A cláusula compromissória, como convenção entre as partes, é obrigatória. Após a Lei 9307/96, a cláusula compromissória deixou de ser facultativa'. Se a lei alcançar os efeitos futuros de contratos celebrados anteriormente a ela, será essa lei retroativa (retroatividade míni$\mathrm{ma}$ ), porque vai interferir na cláusula (art. $5^{\circ}, \mathrm{XXXVI,} \mathrm{da} \mathrm{CF).} \mathrm{"As} \mathrm{dispo-}$ sições processuais da Lei $9.307 / 96$, têm incidência imediata nos casos pendentes de julgamento. A cláusula arbitrai tem o efeito de afastar a competência do Judiciário para decidir a controvérsia nascida do contrato'.

(...)" (n/grifo)

Além do já citado dever de sigilo, o juízo arbitral se caracteriza ainda pela possibilidade de adoção da eqüidade, caso assim convencionem as partes (art. $2^{\circ}$, caput), que poderão "escolher, livremente, as regras de direito que serão aplicadas na arbitragem, desde que não haja violação aos bons costumes e à ordem pública" (art. $\left.2^{\circ}, \mathrm{I}\right)$. Do mesmo modo, "Poderão, também, as partes, convencionar que a arbitragem se realize com base nos princípios gerais de direito, nos usos e costumes e nas regras internacionais de comércio", o que é de difícil aplicação prática na atividade jurisdicional do Estado.

16 BRASIL. Tribunal de Justiça do Estado do Rio de Janeiro. Agravo de Instrumento. Processo $\mathrm{n}^{\circ}$ 2003.002.00841. Órgão Julgador: Décima sexta Câmara Cível. Relator: Desembargador Ronald Valladares. Data de Registro: 19.08.2003. Julgamento: 24.06.2003. 
Os árbitros também podem ser escolhidos livremente pelas partes, com base no conhecimento, respeitabilidade e na confiança que estas neles depositem, o que não representa o literal entendimento acerca do princípio do juiz natural e da livre distribuição dos feitos entre os juízos competentes na Comarca.

Tem-se, assim, que a principal característica da Lei de Arbitragem brasileira é o resgate do princípio da autonomia da vontade, desde a decisão de submeter o litígio ao juízo arbitral — seja na cláusula arbitral, seja no compromisso arbitral —, na eleição do árbitro - escolhido livremente por elas —. e mesmo na determinação do critério a ser utilizado pelo árbitro na decisão do conflito.

No que tange ao consagrado princípio da autonomia da vontade, o Desembargador Gilberto REGO ${ }^{17}$, integrante do Egrégio Tribunal de Justiça do Estado do Rio de Janeiro, assim decidiu:

$\cdots(\ldots)$

Direito Empresarial. 'Arbitragem. A arbitragem é instância judicial praticada em função de regime contratualmente estabelecido para dirimir controvérsias. A fonte da arbitragem é a autonomia das partes que a adotam para solucionar os litigios que possam vir a surgir entre elas. A concepção moderna do contrato enfatiza o caráter de cooperação entre os contraentes buscando os fins econômicos e sociais que levaram ao encontro de vontades na sua formação'. Na convenção de arbitragem estão compreendidas a cláusula compromissóría e compromisso arbitral (Lei $n^{\circ} 9.307$, de 23 de setembro de 1996, art. $3^{\circ}$.). (...)" (n/grifo)

De fato, considerando-se que o princípio da livre iniciativa tem como um de seus corolários o "princípio da subsidiariedade", se as partes não dependem de uma atuação estatal para solucionarem seus conflitos e retornarem a uma situação de equilibrio, não é legítimo ao Poder Público substituir impositivamente tal vontade privada pela vontade estatal. Trata-se, pois, em última análise, de um instituto que dá aplicabilidade a esse fundamento da República, reconhecido no artigo $1^{\circ}$ da Lei Maior.

Joel Dias FIGUEIRA JÚNIOR ${ }^{18}$ afirma a propósito que:

"... 'o mito do monopólio da jurisdição ${ }^{19}$ estatal há de ser quebrado' $e$ alardeado como uma boa nova que os ventos trazem para os próximos

17 BRASIL. Tribunal de Justiça do Estado do Rio de Janeiro. Apelação Cível. Processo $n^{\circ}$ 2001.001.28808. Órgão Julgador: Sexta Câmara Cível. Relator: Desembargador: Gilberto Rego. Data de Registro: 26.09.2002. Julgamento: 30.04.2002.

18 In: WALD, Arnoldo. CARNEIRO, Athos Gusmão. ALENCAR, Miguel Tostes de. DOURADO, Ruy Janoni. Da validade de convenção de arbitragem pactuada por sociedade de economia mista. Revista de Direito Bancário, do Mercado de Capitais e da Arbitragem. São Paulo, a. 5, outdez, 2002, p. 411.

19 No sentido que se deu neste estudo à expressão jurisdição em face à expressão justiça, entenda-se, pois, no caso, a referência ao monopólio da justiça. 
temipos. A jurisdição privada, isto é, o 'juizo arbitral', ao lado de outras formas alternativas de solução dos conflitos, inspiram aos jurisdicionados e operadores do direito a tão esperada bonança no recebimento da prestação das tutelas", (n/grifo)

Não há que se confundir compromisso e juízo arbitral: enquanto o primeiro é a forma (ato jurídico bilateral) pela qual as partes podem escolher e nomear árbitros para solucionarem suas pendências, o segundo é a sua conseqüência. Em outras palavras, o compromisso é matéria de direito privado e o juízo arbitral é instituto de direito processual civil, já que traduz o meio procedimental da arbitragem, pelo qual o Estado reconhece uma das formas legalmente aceitas de dizer o direito (e, também neste sentido semântico, não é negativa de jurisdição); o compromisso é pressuposto do juízo arbitral, isto é, aquele pode vir a existir sem necessariamente se instaurar o segundo; todavia, o segundo inexistirá se não precedido pelo primeiro.

Em matéria de arbitragem, o princípio da autonomia da vontade encontra sua especialização tópica no princípio da autonomia da cláusula compromissória, previsto nos arts. $4^{\circ}$ e $8^{\circ}$ da Lei $n^{\circ} 9.307 / 97$ :

"Art. $4^{\circ} \mathrm{A}$ cláusula compromissória é a convenção através da qual as partes em um contrato comprometem-se a submeter à arbitragem os litígios que possam vir a surgir, relativamente a tal contrato.

$\S 1^{\circ}$ A cláusula compromissória deve ser estipulada por escrito, podendo estar inserta no próprio contrato ou em documento apartado que a ele se refira.

$\S 2^{\circ}$ Nos contratos de adesão, a cláusula compromissória só terá eficácia se o aderente tomar a iniciativa de instituir a arbitragem ou concordar, expressamente, com a sua instituição, desde que por escrito em documento anexo ou em negrito, com a assinatura ou visto especialmente para essa cláusula.

\section{(...)}

Art. $8^{\circ}$ A cláusula compromissória é autônoma em relação ao contrato em que estiver inserta, de tal sorte que a nulidade deste não implica, necessariamente, a nulidade da cláusula compromissória.

Parágrafo único. Caberá ao árbitro decidir de ofício, ou por provocação das partes, as questões acerca da existência, validade e eficácia da convenção de arbitragem e do contrato que contenha a cláusula compromissória. "(n/grifo)

J. E. Carreira $\mathrm{ALVIM}^{20}$, ao tratar da cláusula compromissória, expõe que:

"Apesar de autônoma, relativamente ao contrato que acede, a 'cláusula compromissória tem caráter consensual', sendo o ato de vontade de que se

20 ALVIM, J. E. Carreira. Comentários à Lei de Arbitragem (Lei 9.307. de 23.9.1996). Rio de Janeiro: Lumen Júris, 2002, pp. 74 e 75. 
origina diverso daquele que faz nascer o contrato. Dai, por que a nulidade ou invalidado do contrato, em principio, não se estende à cláusula compromissória, salvo se causa de nulidade lhes for comum - como, por exemplo, a incapacidade de um dos contratantes -, caso em que o vício afetará a ambos. A própria questão da nulidade ficará sujeita à cláusula compromissória." (n/grifo)

Em razão dessa autonomia, decorrente da vontade das próprias partes, o Juiz não pode substituir-se a essa intenção para assumir o lugar do árbitro.

De longa data já explanava o Emérito Professor e Desembargador do Tribunal de Justiça do Estado do Rio de Janeiro. Cláudio Vianna de LIMA², estudioso e divulgador do instituto, que:

"Desde que se equipara o árbitro ao juiz (art. 18 da lei), há que se reconhecer ao árbitro a prerrogativa de fazer o primeiro julgamento que faz todo juiz ao apreciar uma questão: o julgamento da própria competência. O juiz é o juiz da própria competência. 'A razão da autonomia da cláusula compromissória está em que a eventual declaração de invalidado da cláusula, por outro julgador', importaria em que este afastasse o árbitro (que não poderia persistir como tal, se eliminada a cláusula compromissória). Com o que estaria eliminando a competência do árbitro em apreciar a própria 'competência. Também é fator para se consagrar a autonomia da cláusula compromissóría a necessidade de prestigiar a arbitragem, dando poderes ao árbitro, evitando-se o desprestígio para o instituto se, a todo momento, se permitir a ida à Justiça comum, atribuindo-se a esta, ainda por cúmulo, o poder de tirar o árbitro do procedimento arbitral."' (n/grifo)

Prosseguindo 22 , afirma que:

"É possível a instauração da arbitragem sem que, antes, exista a cláusula compromissóría. Mas, haja ou não esta cláusula, não é possível instaurá-la sem o compromisso, que tem, aí, não só e propriamente, a função de 'vínculo obrigacional', entre os conflitantes, de utilização da 'alternativa' para resolver a sua divergência, mas, com maior peso, as demais funções do compromisso. 'O vínculo obrigacional, voluntariamente assumido, pelas partes, de se valer da arbitragem na solução de sua divergência, advém da cláusula compromissóría', quando existe, ou da própria e persistente vontade de optar pela arbitragem, que acompanha todo o curso deste procedimento, com a boa fé contínua ínsita na alternativa arbitral.

(...)

21 LIMA, Cláudio Vianna de. Curso de Introdução à Arbitragem. Rio de Janeiro: Lumen Júris, 1999,p.59.

22 LIMA, Cláudio Vianna de. Op. cit. pp. 70 e 74. 
'O compromisso é o ato mais formal do procedimento da arbitragem', contrariando, em princípio, a natureza informal, ou mesmo aformal, das alternativas amigáveis de solução de conflitos de interesse. No caso, no entanto, vistas as distintas funções do compromisso, a forma assegura a exatidão de seus termos e garante a produção dos seus efeitos como desejados. 'Aplica-se, a este mínimo de formalidade' (à vista do excessivo formalismo dos atos do processo comum) 'o principio do Direito Romano: FORMA DAT ESSE REI (a forma dá existência ao instituto', assim traduzida a palavra latina RÉS, que é de sentido mais amplo do que coisa, do que o bem corpóreo).' (n/grifo)

Isso decorre do próprio princípio da subsidiariedade, por força do qual o Estado (Jurisdição) não assume uma competência que os próprios legitimados não the conferiram.

Por fim, Arnoldo WALD. Athos GUSMÃo CARNEIRO, Miguel Tostes de ALENCAR, e Ruy Janoni DOURADO, abordando, agora especificamente, a validade da adoção da arbitragem por sociedade de economia mista, afirmam ${ }^{23}$ :

"A existência de convenção de arbitragem, que abrange tanto a cláusula compromissória como o compromisso arbitral art. 3. da Lei 9.307/96), "é causa expressa de extinção do processo sem julgamento de seu mérito, como estatui, com solar clareza, o art. 267, VIl, do CPC. 'Desconsiderar esse comando judicial significa negar vigência à lei federal inequívoca, com todas as conseqüências disso de 'fluentes"'. (n/grifo)

Não há, pois, como, à luz dos princípios da autonomia da vontade e da subsidiariedade, alterar unilateralmente um vínculo que dimana do consenso; ainda porque, só o árbitro, como primeiro juiz de sua competência, é quem tem, por lei, legitimidade para tanto.

\subsection{A arbitragem e o princípio da jurisdição una}

Muito se tem debatido na doutrina nacional a respeito da natureza jurídica da arbitragem após o advento da Lei $\mathrm{n}^{\circ}$ 9.307/96.

Opiniões de peso afirmam que se trata de natureza jurídica contratual ${ }^{24}$, pelo que a arbitragem se origina de uma convenção entre as partes, e os árbitros nada

23 WALD, Arnoldo. CARNEIRO, Athos Gusmão. ALENCAR, Miguel Tostes de. DOURADO, Ruy Janoni. Da validade de convençāo de arbitragem pactuada por sociedade de economia mista. Revista de Direito Bancário, do Mercado de Capitais e da Arbitragem. São Paulo, a. 5, out/dez. 2002, p. 410.

24 Como descreve CARMONA, Carlos Alberto. (Das boas relações entre os juizes e os árbitros. Revista do Advogado, n 5 , São Paulo, outubro de 1997, p. 18) sustentam pela naturezal privada da arbitragem, reservando a jurisdição unicamente ao Estado, dentre outros: BERMUDES, Sérgio (Introdução ao Processo Civil. Rio de Janeiro: Forense, 1995. p. 21); GRECO FILHO. Vicente. 
mais são do que mandatários comuns das partes, sendo a sentença apenas a manifestação comum da vontade dos interessados.

A Suprema Corte Pátria, em voto proferido pelo saudoso Min. Castro Nunes ${ }^{25}$, assim já se posicionou, verbis:

$"(\ldots)$

O que se 'assegura é o direito a jurisdições regulares', a possibilidade ressalvada de poderem levar a juizo a sua pretensão ou de não responderem senão em juizo, 'do inverso. o Juizo Arbitral supõe, no ato de sua constituição, o acordo das partes que consentem em subtrair a causa às Justiças regulares, estando pelo que decidirem os juizes-arbitros por eles escolhidos'. Jamais se entendeu, aqui ou alhures, que pudesse o compromisso arbitral constituir uma infração daquele principio constitucional. ' (...)" $(n / g r i f o)$

Outros propugnam pelo caráter jurisdicional da arbitragem ${ }^{26}$; a decisão arbitral seria um julgamento ao qual os árbitros chegaram animados pelo contraditório, dando-se a interferência de uma terceira pessoa, estranha à lide, para, imparcialmente, dirigir-se em busca da verdade para a aplicação do direito.

Por fim, ainda há aqueles que sustentam pela natureza jurídica mista ${ }^{27}$ (contratual e jurisdicional), dando-se a adesão voluntária e consensual a um serviço privado mas de relevante interesse público, prestado sob disciplina estatal, pois, afinal, o Estado moderno não é o único titular ou intérprete dos interesses públicos. $O$ que é do interesse geral é o cumprimento das leis e dos contratos, que, no caso em exame, é representado pela preservação da cláusula que estabelece o compromisso de solução de conflitos por meio de arbitragem.

(Direito Processual Civil Brasileiro. São Paulo: Saraiva, 1995, v. I, p. 170): NEVES, Celso. (Estrutura Fundamental do Processo Civil. Rio de Janeiro: Forense, 1995, p. 19); MARQUES, José Frederico (Instituições de Direito Processual Civil. Rio de Janeiro: Forense, 1966, v. I, p. 215 ). Também com esta opiniāo: CÂMARA, Alexandre Freitas. (Arbitragem. Rio de Janeiro: Lumen Júris, 1997, p. 87).

25 RTJ 68/392.

26 São exemplos que acompanham este entendimento: CARMONA, Carlos Alberto. (Das boas relações entre os juizes e os árbitros. Revista do Advogado, $n^{\circ}$ 5, São Paulo, outubro de 1997, p. 18); TEIXEIRA, Salvio de Figueiredo. Arbitragem como meio de solução de conflitos no âmbito do mercosul e a imprescindibilidade da corte comunitária. Revista Jurídica, $\mathrm{n}^{\circ} 236$. São Paulo, ano XLV, junho de 1997, p. 24); THEODORO JÚNIOR, Humberto. (A arbitragem como meio de solução de controvérsias. Revista Síntese de Direito Civil e Processual Civil, $\mathrm{n}^{\circ} 2$, São Paulo, Nov./Dez, 1999, p. 5); WAMBIER, Luiz Rodrigues, et al (Curso avançado de processo civil. 3 , ed. São Paulo: Revista dos Tribunais, 2001, v.l, p. 37).

27 Defende esta opinião MARTINS, Sérgio Pinto (Direito Processual do Trabalho. 15 ed. São Paulo: Atlas, 2001, p. 85): "Na verdade, a natureza juridica da arbitragem é mista, envolvendo o contrato e a jurisdição. A primeira fase é contratual, tendo por base a cláusula compromissária. que decorre do acordo de vontade. A segunda fase é jurisdicional, em que o árbitro irá dizer o direito aplicável à espécie". 
Muito se havia afirmado que a Constituição Federal de 1988 , no seu art. $5^{\circ}$, inciso XXXV, preceituava a inafastabilidade do Poder Judiciário para solucionar litígios. Ocorre que esse dispositivo não antagoniza nem, muito menos ilide os 'princípios da liberdade de contratar' e da 'solução pacífica dos conflitos', que pertencem à órbita do direito privado, por força dos quais as partes podem ajustar que um terceiro resolva possíveis pendências jurídicas, senão que, ao revés, com eles perfeitamente se harmonizam.

No mesmo acórdão anteriormente citado, o TRT da $2^{\mathrm{a}}$ Região ${ }^{28}$ julgou que:

(...)

Com efeito, o 'tema em questão ainda é muito novo em nossa jurisprudência' e esparsos são os 'doutrinadores que se destinam ao seu estudo. Mesmo assim, entendo que a arbitragem não caracteriza renúncia ao exercício do direito de ação e sim uma das formas de se solucionar controvérsias sem precisar da atuação do Poder Judiciário'.

Não se trata de impedir o acesso ao Judiciário, como vem sendo fundamentado por alguns que entendem que a cláusula compromissória fere o art. $5^{\circ}, X X X V$, da $C F / 88$, e sim uma disponibilidade que têm os interessados de virem suas questōes sendo dirimidas com maior celeridade, presteza, com menos entraves burocráticos etc.

Como bem salientado pelo então Procurador-Geral da República, o eminente Doutor Geraldo Brindeiro, em seu Parecer 8.062, Sentença Estrangeira 5.206-8/246-STF, 'a norma constitucional que garante o acesso ao Judiciário' não significa, contudo, que as pessoas físicas ou jurídicas estão obrigadas a ingressar em juizo todas as vezes que seus direitos subjetivos são afrontados por outrem, pois o princípio garante o direito de ação, não o impõe'. O direito de ação, à luz do princípio de autonomia das vontades, representa uma faculdade inerente à própria personalidade, não um dever.'

'Uma vez acordado pelas partes, por forçada cláusula compromissóría, que possíveis litígios serão resolvidos pela instituição da arbitragem, razão não há para se relegar a vontade delas, a sua discricionariedade na solução das controvérsias ocorrentes.

Se uma das partes alega descumprimento de cláusulas contratuais, ensejando rescisões e ressarcimentos no âmbito de nossas cortes, não vejo razão de se negar a instituição da arbitragem, sob o fundamento que a pretensão é impossivel por que não houve qualquer tipo de burla contratual'. (...)" (n/grífo)

28 BRASIL. Tribunal Regional do Trabalho da 2ن Região. RO 2001.041.5240. Órgão Julgador: Sexta Turma. Julgamento: 05.03.2002. Relator: Juiz Altair Berty Martinez. 
Igual entendimento já assentou o Ministro Gueiros Leite, do Superior Tribunal de Justiça ${ }^{29}$ :

“(...)

'Arbitragem. Validade de cláusula compromissória. A Constituição proíbe que lei exclua da apreciação do Poder Judiciário lesão ou ameaça a direito (art. 5. XXXV). Ela não proíbe que as partes pactuem formas extrajudiciais de solução de seus conflitos, atuais ou futuros. Não há nenhuma vedação constitucional a que partes, maiores e capazes, ajustem a submissão de conflitos, que possain decorrer de relações jurídicas decorrentes de contrato especifico, ao sistema de arbitragem. Não há renúncia abstrata à jurisdição. Há, isto sim, 'convenção de arbitragem' sobre litígios futuros e eventuais, circunscritos a especifica relação contratual, rigorosamente determináveis. (...)" (n/grifo)

Daí porque, em defesa da constitucionalidade da arbitragem, esclarece com sua habitual precisão Adilson Abreu DALLARI ${ }^{30}$ :

"Em primeiro lugar, cabe ressaltar que ao optar pela arbitragem o contratante público não está transigindo com o interesse público nem abrindo mão de instrumentos de defesa de interesse públicos. Está, sim, escolhendo uma forma mais expedita ou um meio mais hábil para a defesa do interesse público. Assim, como o juiz, no procedimento judicial, deve ser imparcial, também o árbitro deve decidir com imparcialidade. O interesse público não se confunde com o mero interesse da Administração ou da Fazenda Pública; o interesse público está na correta aplicação da lei e se confunde com a realização concreta da justiça. Inúmeras vezes, para defender o interesse público, é preciso decidir contra a Administração Pública.

Em segundo lugar, a lei instituidora ou disciplinadora da arbitragem nos contratos administrativos não está vedando o acesso ao Poder Judiciário, mas, sim, apenas proporcionando uma alternativa, que pode ser utilizada com maior ou menor intensidade, para certas espécies de conflitos (por exemplo, questôes técnicas ou econômicas), não havendo possibilidade alguma de se excluir totalmente o controle jurisdicional da Administração Pública, conforme se demonstrará mais adiante.

(...)

A adoção da arbitragem como forma amigável de solução de divergências na execução de contatos administrativos nāo se choca com a regra, cons-

29 BRASIL. Superior Tribunal de Justiça. Recurso Especial n 616 - RJ (198900098535). Relator: Cláudio Santos. Órgão Julgador: Terceira turma. Data da decisão: 24.04.1990, Fonte: DJ data: 13/08/1990. P. 7.647 RSTJVOL.: 37. p: 263.

30 DALlARI, Adilson Abreu. Arbitragem na Concessão de Serviço Público. Boletim de Direito Municipal. São Paulo, n 11. nov., 2001. pp. 798 e 799. 
titucionalmente estabelecida, no sentido de que nenhuma lesão de direito pode ser subtraída ao exame do Poder Judiciário."

Luiz Felipe Azevedo GOMES ${ }^{31}$, do mesmo modo, afirma:

"(...) o exame desapaixonado da Lei $n^{\circ} 9.307 / 96$ leva à conclusāo de que ela não está eivada de inconstitucionalidade. A uma, porque a natureza contratual da arbitragem permite sua sobrevivência, em que pese o monopólio estatal da jurisdiçāo. Monopólio que só poderia ser afetado na hipótese, aqui inocorrente, de que a lei tornasse compulsória sua utilização. A duas, porque nem compromisso, nem o processo e a sentença arbitral estão fora da apreciação do Judiciário, relevando notar que o art. 32 prevê tão minuciosamente, como o art. 1.100 do CPC, as hipóteses de nulidade da sentença arbitral.

No mesmo diapasão. Hamilton de Moraes e Barros que, ao comentar o Código de Processo Civil vigente. com sua dupla autoridade de magistrado e doutrinador, escreveu: "O JUÍZO ARBITRAL E A CONSTITUIÇÃO constitui erro grosseiro de direito dizer-se que a Constituição proibiu o juizo arbitral, quando, no art. $153, \$ 4^{\circ}$, declara que a lei não poderá excluir da apreciação do Poder Judiciário qualquer lesão do direito individual.

Nem a Constituição atual, nem as que antecederam contêrn essa proibição. Ao juizo arbitral podem recorrer as partes, se o preferirem à jurisdição estatal, para solução de suas controvérsias. $O$ que as Constituições não admitem, nem toleram, é que os indivíduos e pessoas, ainda que queiram, não possam recorrer ao Poder Judiciário, porque a lei tenha fechado esse caminho.

'Ao prever o juizo arbitral e ao discipliná-lo, não está a lei excluindo a lesão ao direito individual, ou pessoal, da apreciação do Poder Judiciário. Está, apenas, oferecendo às pessoas mais am meio - facultativo - de acertarem as suas relações." (Comentários ao Código de Processo Civil, Forense, $l^{a}$ ed, (X/377)

Por fim, GERALDO BRINDEIRO assim se pronuncia ${ }^{32}$ :

"A Lei n'9.307/96 guarda completa harmonia com as garantias e direitos assegurados pela Constituição Federal, especialmente com o princípio da inafastabilidade do controle jurisdicional, inscrito no art. $5^{\circ}$, inciso $X X X V$. Essa norma constitucional assegura a todos o acesso à justiça nas hipóteses de lesão ou ameaça a direito, que pode se concretizar através do ajuiza-

31 GOMES, Luiz Felipe Azevedo. A intervenção do Estado na Arbitragem. Ajuris. Porto Alegre: ano XXIV, Março/1997, n 69. pp. 369-374.

32 In: LIMA. Cláudio Vianna de. Curso de introdução à arbitragem. Rio de Janeiro: Lumen Júris, 1999, pp. 327 e 328. 
mento de ação judicial. Isto não significa, contudo, que as pessoas físicas ou jurídicas estão obrigadas a ingressar em juizo toda a vez que seus direitos subjetivos são afrontados por outrem, pois o princípio garante o direito de ação, não o impõe. $O$ direito de ação, à luz do princípio da autonomia das vontades, representa uma "faculdade inerente à própria personalidade". não um dever (vide Cândido Rangel Dinamarco, in Execução Civil, Malheiros Editores, $4^{a}$ ed. p. 364).

$O$ que o princípio da inafastabilidade do controle jurisdicional estabelece é que 'a lei não excluirá da apreciação do Poder Judiciário lesão ou ameaça a Direito'. Não estabelece que as partes interessadas não excluirão da apreciação judicial suas questões ou conflitos.

Não determina que os interessados devem sempre levar ao judiciário suas demandas. Se se admite como lícita a transação relativamente a direitos substanciais objeto da lide, não se pode considerar violência à Constituição abdicar do direito instrumental de ação através de cláusula compromissória. E, em se tratando de direitos patrimoniais disponiveis, não somente é lícito e constitucional, mas é também recomendável aos interessados diante do acúmulo de processos e do formalismo excessivo que têm gerado a lentidão das demandas judiciais - abdicarem do direito ou do poder de ação e buscarem a composição do conflito por meio de sentença arbitral cujos efeitos sejam idênticos àqueles das decisões prolatadas pelo Poder Judiciário."

E, assim, o Egrégio Supremo Tribunal Federal já decidiu pela constitucional idade dos arts. $6^{\circ} \mathrm{e} 7^{\circ}$ da Lei, admitindo a validade do compromisso arbitrai, condição para a utilização da arbitragem ${ }^{33}$.

Dessa forma, a admissibilidade do compromisso exige a plena capacidade dos seus signatários, que não podem estar impedidos para a prática dos atos da vida civil e a possibilidade de dispor dos direitos em controvérsia, além da capacidade de serem parte em juízo.

Resta examinar se existe algum impedimento específico referido a uma sociedade de economia mista, sujeita à Lei das Sociedades Anônimas (ref. a seu art. 235).

33 Decisão: O Tribunal, por unanimidade, proveu o agravo para homologar a sentença arbitral, vencidos parcialmente os senhores Ministros Sepúlveda Pertence, Sydney Sanches, Néri da Silveira e Moreira Alves, no que declaravam a inconstitucionalidade do parágrafo único do artigo $6^{\circ}$ : do artigo $7^{\circ}$ e seus parágrafos; no artigo 41 , das novas redações atribuídas ao artigo 267 , inciso VII, e ao artigo 301, inciso IX, do Código de Processo Civil; e do artigo 42, todos da Lei $n^{\circ} 9.307$, de 23 de setembro de 1996. Votou o presidente, o senhor Ministro Marco Aurélio. Plenário, 12.12.2001. (BRASIL. Supremo Tribunal Federal. Agravo Regimental em Sentença Estrangeira. SE ${ }^{\circ} 5206 /$ EP AGRG. REQTE.: M B V COMMERCIAL AND EXPORT MANAGEMENT ESTABLISHMENT, REQDO.: RESIL INDÚSTRIA E COMÉRCIO LTDA. Relator: Ministro Presidente. Julgamento: 12.12.2001. Publicação: 19.12.2001). 


\section{Arbitragem na Administração Pública}

\subsection{A Lei $n^{\circ} 8.666 / 93$}

Não obstante os ponderáveis posicionamentos da doutrina e da jurisprudência apresentados, discute-se, ainda, se a Administração Pública poderia fazer uso da cláusula de arbitragem nos contratos administrativos, ante o disposto no art. 55, § $2^{\circ}$, da Lei $n^{\circ} 8.666 / 93$ - que impõe como cláusula obrigatória dos contratos a indicação do foro judicial competente para a solução de controvérsias.

De longa data se tem insistido nesta matéria ${ }^{34}$, propondo uma revalorização da consensualidade, com o emprego de soluções adicionais para a realização da justiça e a composição de interesses em conflito, eis que:

"(...) essa prerrogativa não envolve, não elimina nem prejudica a busca da justiça, enquanto anseio e atividade humana que não é monopólio de ninguém, nem mesmo de organizaçóes políticas.

(...) os interesses são projeções das necessidades, que todas as pessoas e todas as sociedades humanas procuram satisfazer através de bens e serviços a seu alcance. São, assim, as próprias pessoas, individualmente ou organizadas, que se encarregam de prover à maior parte de seus respectivos interesses, desenvolvendo-se, com isso, o mercado.

\section{(..)}

no mercado, tudo, em regra, é disponível, como corolário inafastável do princípio constitucional fundamental que entroniza os valores sociais do trabalho e da livre iniciativa

Em outros termos e mais sinteticamente: está-se de duas categorias de interesses públicos, os primários e os secundários (ou derivados), sendo que os primeiros são indisponíveis e o regime público é indispensável, ao passo que os segundos têm natureza instrumental, existindo para que os primeiros sejam satisfeitos, e resolvem-se em relações patrimoniais e, por isso, tornaram-se disponíveis na forma da lei, não importando sob que regime."

E, realmente, a busca dessa clivagem na natureza de interesses já se faz antiga, mesmo considerada a relativa juventude do Direito Administrativo entre as disciplinas jurídicas, pois ${ }^{35}$ :

"Essa distinção entre as atividades administrativas, com o propósito de definir quais as que se situam ou podem se situar no campo do direito 
privado, ou seja, naquele em que prevalecem a autonomia da vontade e a disponibilidade, tem sido buscada de longa data no Direito Administrativo. Na esteira da então chamada doutrina do fisco, construiu-se a separação entre atos de império (ou de autoridade) e atos de gestão, que prevaleceu durante todo o século XIX (...)"

Reforçando a improcedência do argumento, afirma Fernando Antônio Dusi ROCHA ${ }^{36}$ :

"Com o passar dos anos, à vista das necessidades, 'o direito positivo brasileiro veio aceitando, gradativamente, a participação do Estado em arbitragens privadas'. Embora fosse discutivel sua admissão pelo art. 775 , " $e$ " do Regulamento Geral de Contabilidade, aprovado pelo Decreto $n^{\circ}$ 15.783/22, diplomas posteriores admitiram expressamente tal possibilidade. ' $O$ art. 23 da Lei $n^{\circ}$ 1.268, de 20 de junho de 1952, permitiu ao Tesouro Nacional, contratando diretamente ou por meio do BNDE, aceitar o compromisso geral e antecipado de dirimir, por arbitramento, todas dúvidas e controvérsias' decorrentes de operaçōes com organismos financiadores internacionais. $O$ art. 11 do Decreto-lei $n^{\circ} 1.312$, de 15 de fevereiro de 1974 reproduziu tal disposição, confirmando a submissão da União ao compromisso arbitral" (n/grifo)

O referido autor ${ }^{37}$, seguindo esta vertente, continua:

"No curso de um contrato administrativo, 'o conflito de interesses inercial permanece latente'. Se manifestada a desavença, deverá haver predominância do interesse público sobre o particular. Em se tratando de contratos administrativos típicos, em que é patente a desigualdade jurídica em favor da administração, não há dificuldade em se invocar o interesse público primário no sacrifício do 'interesse do particular'. Em se tratando de contratos de direito privado, nos quais, mesmo com estrita observância dos princípios orientadores da atividade administrativa, 'a Administração queda-se aos moldes privatísticos, por opção ou por necessidade, a relação se estabelece em condições de igualdade com o particular, agindo ela como ente privado, onde prepondera interesse próprio do aparelho organizativo. Nestes casos, os interesses se parificam, porquanto não há desigualdade juridica que justifique o sacrificio do particular.

No contexto dos 'contratos firmados pela Administração, sujeitos ao regime privatístico. é que parece legítimo o recurso à arbitragem na solução de conflitos que não repercutam na esfera dos interesses primários', pressupondo-se que a valoração dos interesses passiveis de convenção arbitral

36 ROCHA, Fernando Antônio Dusi. Regime Jurídico dos Contratos da Administração. 2. ed. Brasília: Brasília Jurídica, 2000, p. 285.

37 ROCHA, Fernando Antônio Dusi. Op. cif. p. 290 e 291. 
seja feita pelo órgão administrativo competente, necessariamente autorizado por lei. Decerto que 'tal avaliação defluirá do legítimo exercício do poder discricionário, à vista da amplitude do interesse a ser protegido', numa situação concreta.

(...)

A 'tendência de flexibilidade do direito administrativo justifica e motiva a superação do modelo tradicional da atividade administrativa', radicada numa relação de subordinação. A realidade do dia-a-dia das administrações demonstra a necessidade de serem removidos os obstáculos, impostos pela própria potestade do ente público." (n/grifo)

$\mathrm{Na}$ atualidade, os doutrinadores ainda discutem sobre sua viabilidade. Assim é que Luís Roberto BARROSO ${ }^{38}$ sustenta que:

"Na verdade, a conviç̧ão que se chegou do exame das regras e princípios pertinentes é que, em determinados casos, 'a Administração poderá sim submeter-se à arbitragem', mas essa possibilidade teórica não se toma viável com a mesma facilidade e simplicidade com que se passa entre os particulares. Será indispensável o adimplemento de alguns 'requisitos'. dentre os quais, o 'mais importante, é a existência de lei autorizando' a Administração a submeter-se à arbitragem, o que, no caso do ajuste examinado. não se verificou." (n/grifo)

Já JOSÉ EMÍLIO NUNES PINTO ${ }^{39}$ afirma que, até então, ainda que sujeitas a julgamento de recursos interpostos, as decisões administrativas e judiciais se posicionam pela ilegalidade da arbitragem nesse caso. Resume o autor o seguinte:

"En linhas gerais, as decisões que negam validade às cláusulas compromissórias se fundam (i) na violaçāo do princípio da legalidade, (ii) na violação do princípio da publicidade e (iii) na violação do princípio da supremacia do interesse público sobre o particular. Por todos esses argumentos, as decisões existentes inquinam de nulidade a cláusula compromissória e como conseqüência. determinam a substituição da arbitragen pela submissão aos tribunais estatais ou determinam a suspensão de procedimentos arbitrais instaurados com base em cláusula compromissória. com efeito, vinculante."

Convém enfrentar cada um desses pontos.

38 BARROSO, Luís Roberto. Temas de direito constitucional. Renovar: Rio de Janeiro, 2003, Tomo II, p. 614.

39 PINTO, José Emílio Nunes. A arbitrabilidade de controvérsias nos contratos com o estado empresas estatais. http://www.mundolegal.com.br/?FuseAction=Artigo_Detalhar\&did=13566. Acesso em: 11.11.2003. 


\subsubsection{O principio da legalidade}

Argumentam que, para que o Estado ou empresas estatais prevejam a arbitragem em seus contratos, necessário será que sejam detentores de habilitação legal, ou seja, que a lei os permita utilizar a arbitragem como meio de solução de controvérsias contratuais ${ }^{40}$.

Lúcia Valle FIGUEIREDO ${ }^{41}$ assim leciona:

". Por força do dispositivo do inciso XV do art. 23 da Lei n' 8.987/1995, que dispõe ser necessário constar do contrato o foro e o modo amigável de solução das divergências contratuais, cogitou-se da possibilidade de se utilizar o juizo arbitral'.

Ocorre que, consoante pensamos, o juizo arbitrai, nos termos da Lei $n^{\circ}$ 9.307, de 23.9.1996, estaria, com a vênia devida daqueles que pensam em contrário, absolutamente descartado.

A uma, 'porque destina-se aos direitos disponíveis, portanto näo poderia servir para dirimir questōes em que está envolvido o interesse público'.

Demais disso, nos termos do art. 18 da mencionada Lei $n^{\circ} 9.307 / 1996$, 'o árbitro é juiz de fato e de direito, e a sentença que proferir não fica sujeita a recurso ou a homologação pelo Poder Judiciário', o que implicaria inipossibilidade de haver recurso ao Judiciário, em franco desrespeito às regras constitucionais dos direitos e garantias individuais, (art. $5^{\circ}$, incisos $X X X V, L X I X, L X X$ e LXXIII).

Além disso, as regras de competência processual no tocante às questōes da União são de ordem constitucional, não podendo, à evidência, ser derrogadas por legislação infraconstitucional.

Nem se fale que Estados, Municípios e Distrito Federal poteriam dispor sobre a arbitragem na legislação que fizessem, respeitadas as normas gerais nacionais. Não podem.

Evidentemente, as normas de arbitragem caracterizam-se como normas de processo civil, cuja legislação está afeta privativamente à União, nos termos do art. 22, inciso l, da Constituição da República." (n/grifo)

Os argumentos não são irrebatíveis; inicialmente, se a arbitragem não puder ser aplicada aos contratos previstos na Lei $n^{\circ} 8.987 / 95$, nenhuma utilidade terá o seu art. 23, XV. Frise-se que aqui está-se diante de uma relação privada, decorrente de um contrato de concessão entre a estatal e o poder concedente dos serviços de energia.

40 BARROSO, Luís Roberto. Op. cit, p. 620. Vem lembrar que no entanto: “(...) o que tem causado alguma controvérsia. é a disposição de segmentos da doutrina em defencler a possibilidade de clausular-se a arbitragem nos contratos administrativos em geral (deforma mais ou menos ampla), buscando fundamento para tanto em referências legislativas longinquas que não parecem fornecê-lo".

41 FIGUEIREDO, Lúcia Valle. Curso de direito administrativo. 6. ed. São Paulo: Malheiros, 2003, p. 106. 
A competência constitucional da Justiça Federal não é excluída nos casos de arbitragem, como já reconhecido nas decisōes acima citadas, no sentido de inexistência de renúncia à jurisdição, a qual, como visto, não é privativa do Estado, com fundamento nos princípios da livre iniciativa e da subsidiariedade.

Ademais, tal competência de foro (CF, art. 109, 1) não abrange as sociedades de economia mista (apenas as empresas públicas) - valendo citar que, no caso em exame, o contrato prevê uma cláusula contemplando o foro da Administração para as questões que não envolverem interesses disponíveis (que, portanto, não puderem ser solucionadas pelo juízo arbitral).

O conflito se submete, pois, à luz dos princípios constitucionais da livre iniciativa e da autonomia da vontade, ao método previsto na lei federal competente para autorizar o uso da arbitragem. Tal norma tem o mesmo status - de norma de direito empresarial - da Lei de Sociedades por Ações - Lei n 6.404/76 - que submete as sociedades de economia mista à sua disciplina.

Conclui-se, portanto que existe cabal autorização legislativa para a adoção da arbitragem por empresa estatal.

Acresce que mesmo em um típico contrato administrativo, como é o caso da concessão de serviço público, é expressamente reconhecida a possibilidade de adoção da arbitragem, porque neles existem aspectos que são puramente patrimoniais e não podem ser confundidos com os aspectos de serviço, esses sim, recobertos pela indisponibilidade, como observa Toshio $\mathrm{MUKAI}^{42}$, ao tratar do inciso XV do art. 23 da Lei ${ }^{\circ} 8.987 / 95$ :

"A possibilidade da previsão contratual de modo amigável é a maior inovação do inciso VX do art 23, pois permite que a Administração negocie, que abra mão de certos interesses em favor de outros mais relevantes. $E$ possivel também a arbitragem.

A maioria dos problemas que surgem nas concessões é de ordem técnica, que necessita de perícia para a 'solução, atividade que se tem demonstrado muito mais célere e eficaz na arbitragem que no âmbito do Judiciário.

No entanto deve-se ressaltar que não caberá a solução amigável em questões que digam respeito a assunto ao qual a lei não permita transação, como, por exemplo, a controvérsia que dependa de declaração de inconstitucionalidade de lei ou ato normativo, (n/grifo)

Carlos Pinto Coelho da MOTTA ${ }^{43}$ discorre que:

"Ocorre atualmente grande evolução nessa matéria, já identificada na legislação mais recente, mormente nas leis n 8.987/95 e 9.307/96. Todavia, a doutrina, mesmo anterior a essas leis, já admitia a transação na Administração Pública."

42 MUKAI Toshio. Direito Administrativo Sistematizado. São Paulo: Saraiva, 1999. p. 460.

43 MOTTA. Carlos Pinto Coelho. Arbitragem nos Contratos Administrativos. Boletim de Direito Administrativo. $\mathrm{n}^{\circ} 10$, out. 1997, pp. $673-676$. 
Com citação do ensinamento de Almiro Couto e SILVA, o autor acima ${ }^{44}$ expõe:

"A Administração Pública, quando celebra transação, sujeita-se ao Direito Privado. Cabe-lhe, pois, transigir da mesma maneira como os particulares, suprimindo dúvidas quanto à invalidado de ato jurídico, o qual é assim por ela mantido. Não fica o Estado inibido de proceder dessa maneira pelo princípio da legalidade da Administração Pública."

Não há, pois. fundamento para se reputar que o uso da arbitragem por uma sociedade de economia mista viole o princípio da legalidade.

\subsubsection{O princípio da publicidade}

Questiona-se que o sigilo inerente à arbitragem violaria o princípio da publicidade.

Ora, tanto a lei quanto as normas procedimentais são públicas, assim como os atos processuais.

José Maria Rossani GARCEZ ${ }^{45}$ afirma:

"A Câmara de Comércio Internacional editou em 2001 regras sobre ADR (Alternativo Dispute Resolution ou Amicable Dispute Resolution). Tais regras se encontram no chamado Regulamento ADR e na Guia ADR da CCl. $O$ regulamento visa pernitir às partes anuírem acerca da técnica de soluçäo amigável mais apropriada para ajudá-las a resolver o seu conflito. Conforme o Regulamento, se não houver acordo pelas partes sobre a técnica mais apropriada para a solução de seu conflito a CCl aplicará a mediação para solucioná-lo.

(...)

A CCI administra uma série de mecanismos não adversariais para soluçāo de conflitos além da mediação tradicional, envolvendo técnicas de negociação, mediação e arbitragem e da combinação entre elas. As regras de ADR da entidade não afastam a faculdade das partes escolherem a técnica que elas crêem possa ser a mais apropriada para a solução da controvérsia entre elas."

EDUARDO SILVA ROMERO ${ }^{46}$ completa tal afirmação demonstrando como se dá o procedimento:

44 In: MOTTA, Carlos Pinto Coelho. Arbitragem nos Contratos Administrativos. Boletim de Direito Administrativo. $n^{\circ} 10$, out, 1997, pp. 673-676.

45 GARCEZ, Josć Maria Rossani. Técnicas de Negociação - Resolução Alternativa de Conflitos: ADRS. Mediação. Conciliação e Arbitragem. Rio de Janeiro: Lumen Júris, 2002. pp. 79 e 80.

46 ROMERO, Eduardo Silva. A Arbitragem da Câmara de Comércio Internacional (CCl) e os Contratos de Estado. Revista de Direito Bancúrio, do Mercado de Capitais e da Arbitragem. São Paulo, a. 6, jan/mar. 2003, pp. 289 e 290. 
"A prática da Corte Internacional de Arbitragem visa, ainda, a assegurar quando da constituição do tribunal arbitrai, o interesse público protegido pelas pessoas jurídicas de direito público. Nós poderemos constatá-lo em três etapas do procedimento: a determinação do número de árbitros, o exame da independência dos árbitros designados pelo Estado ou por uma de suas emanações e a nomeação de um árbitro no lugar de uma parte estatal recalcitrante.

(...)

Em primeiro lugar, o termo pode se reportar à importância do montante em litígio. Por meio de uma presunção, a Corte Internacional de Arbitragem induz a partir de um montante mais ou menos elevado o grau de complexidade do diferendo. O raciocínio é o seguinte: quanto mais elevada é a soma, maior a probabilidade que as dificuldades juridicas ou técnicas apareçam no curso do procedimento, sendo essas dificuldades melhor resolvidas por um tribunal arbitral de três membros do que por um árbitro único.

Em segundo lugar, a constituição de um tribunal arbitral de três membros se justifica, de acordo com a prática da Corte Internacional de Arbitragem, quando um litígio comporta dificuldades jurídicas sobre o mérito ou relativas ao procedimento. Por exemplo, os negócios que suscitam questöes dificeis sobre a competência do tribunal arbitral ou dos pontos litigiosos juridicamente complicados seriam melhor decididos por um tribunal arbitrai de três membros do que por um árbitro único.

Associando esses dois critérios, a Corte Internacional de Arbitragem se inclina a submeter a um árbitro ánico um litígio colocando em causa uma soma importante que se revela ser mais simples e, portanto, fácil de decidir. e de submeter a um tribunal arbitral de três membros um litígio que coloca em jogo uma soma mediana mas envolvendo, por outro lado, dificuldades jurílicas notáveis.

Enfim, em terceiro lugar, a 'Corte Internacional de Arbitragem considera um litígio como suscetivel de ser complexo quando ele envolve uma parte estatal. A complexidade advém do fato de que tais litigios implicam (i) problemas complicados relativos à competência do tribunal arbitral (arbitrabilidade subjetiva), (ii) a aplicação de regras imperativas ou outras do Estado da pessoa jurídica de direito público em questão, (iii) dos riscos para toda uma população' (como, por exemplo, quando o litígio versa sobre a construção de uma barragem ou de uma central elétrica), e (iv) a interferência de interesses e de forças políticas.

(...)

O exame preliminar da sentença arbitral pela Corte Internacional de Arbitragem é uma das características mais relevantes da arbitragem CCl. A maioria das minutas de sentenças arbitrais é examinada pela Corte, reunida na forma de um comitê restrito. Considerando a importância dos litígios decorrentes dos contratos de Estado e do caräter geralmente delicado das questōes que se apresentam nesse tipo de caso, as sentenças dai decorrentes são normalmente examinadas em sessão plenária. 
O exame preliminar da minuta de sentença arbitral pela Corte Internacional de Arbitragem reunida em sessão plenária implica (i) que o numero de membros da Corte a examinar a minuta e a participar do debate sobre sua aprovação será muito superior ao nimero de membros que compõem o comitê; (ii) que alguns desses membros serão da mesma cultura que a parte estatal em questão e poderão, conforme o caso, sensibilizar a Corte quanto aos riscos políticos, econômicos e humanos do litígio e (iii) que, segundo a prática da Corte. um dos seus nembros será encarregado de atuar na qualidade de relator e. depois de apresentar as circunstancias do caso, analisará a minuta da sentença arbitral e recomendará aus seus pares uma decisão de aprovação, de aprovação condicionada ou não-aprovação da minuta da sentença. Esse dispositivo permite, em nosso ver, assegurar uma certa proteção do interesse público que se encontra por trás da parte estatal quando o litigio versa sobre um contrato de Estado.

(...)

Nossa análise mostra que em 'matéria de contratos de Estado a linguagem jurídica é tão-somente um instrumento de valores políticos e econômicos. Nem o direito positivo, nem a doutrina encontraram, em nossa opinião, um equilíbrio entre a posição econômica e a posição política. Por outro lado, a prática arbitral, e notadamente a da CCl, soube conciliar as duas tendências e inspirar confiança nas partes. As decisöes dos árbitros CCI quanto à arbitrabilidade do litígio e as regras e práticas da Corte acerca do exame prima facie das comvenções de arbitragem, a fixação do local da arbitragem, as medidas provisórias e conservatórias, o alcance do consentimento na convenção de arbitragem, a constituição do tribunal arbitral e o exame preliminar da sentença arbitral constituem um quadro juridico onde os interesses privados e o interesse público encontram seu lugar'." (n/grifo).

No entanto, determinados atos processuais, por exporem a intimidade técnica e financeira da empresa à concorrência desleal, são constitucionalmente protegidos.

Dispõe a Constituição Federal de 1988:

\section{"Art. $5^{\circ}$}

(...)

XXIX - a lei assegurará aos autores de inventos industriais privilégio temporário para sua utilização, bem como 'proteção às criações industriais', à propriedade das marcas, aos nomes de empresas e a outros signos distintivos, tendo em vista o 'interesse social e o desenvolvimento tecnológico e econômico do Pais':"(n/grífo)

Vale lembrar que mesmo em processo judicial o acesso de terceiros a informações contidas nos autos 'é limitado', assim como as partes podem requerer seu processamento em segredo de justiça. O Código de Processo Civil Brasileiro - Lei $n^{\circ} 5.869$, de 11 de janeiro de 1973 - assim dispõe: 
“Art. 155. Os 'atos processuais são públicos. Correm, todavia, em segredo de justiça os processos":

l- em que o exigir o interesse público;

(...)

Parágrafo único. ' $O$ direito de consultar os autos e de pedir certidões de seus atos é restrito às partes e a seus procuradores'. O terceiro, que demonstrar interesse jurídico, pode requerer ao juiz certidão do dispositivo da sentença. bem como de inventário e partilha resultante do desquite." (n/grifo)

Por fim, esclareça-se que o sigilo é um dever do árbitro (art. $13, \S 6^{\circ}$ da Lei $n^{\circ}$ 9.307/97), mas uma faculdade da parte.

Destarte, de mesmo modo que o anterior, o argumento de violação ao princípio da publicidade tampouco é plausível para afastar a adoção voluntária do juízo arbitral, na forma livremente pactuada.

\subsubsection{O princípio da supremacia do interesse público}

A idéia de supremacia do interesse público já está, de há muito, repensada no Estado contemporâneo, como bem adverte, na vanguarda da doutrina brasileira, Humberto Bergman ÁVILA ${ }^{47}$ :

"O seu contelido nomativo pressupõe, portanto, a "possibilidade de conflito entre o interesse público e o interesse particular no exercício da função administrativa', cuja solução deveria ser (em abstrato e em princípio) em favor do interesse público.

(...) o 'principio da supremacia do interesse público sobre o particular' (...) como vem sendo descrito pela doutrina, 'não se identifica com o bem comum'. Bem comum é a própria composição harmônica do bem de cada um com o de todos; não, o direcionamento dessa composição em favor do 'interesse púbico'. (...) Não a pressupõe como algo pré-decidido ou mesmo a ser decidido em favor do interesse público." (n/grifo)

O mesmo se diga acerca de seu corolário, que é a 'indisponibilidade do interesse público', que não resta frustrada pela possibilidade de a Administração negociar e mesmo transacionar

(...) mas essa possibilidade é mais restrita, dependendo dos termos da decisão terminativa do feito e da eventual repercussão sobre direitos de terceiros. O norte sempre haverá de ser o interesse público, entendido não como mero interesse da Fazenda Pública, mas, sim, como interesse da coletividade de cidadãos."

47 ÁVILA. Humberto Bergmann. Repensando o Principio da supremacia do interesse público sobre o particular. In: O Dircito Público $\mathrm{cm}$ Tempos de Crise. Porto Alegre: Livraria do Advogado, 1999, pp. $100,101,118$ e 119. 
Para Luís Roberto BARROSO ${ }^{48}$, tudo se resolve tendo em vista a característica da disponibilidade ou indisponibilidade, citando Caio TÁCITO:

"Em suma, nem todos os contratos administrativos envolvem, necessariamente, direito indisponível da Administração.

(...)

Se, indubitavelmente, em certos casos, o principio da indisponibilidade do interesse público repele o compromisso arbitral, não há porque obstar o benefício da transação quando a natureza da obrigaçāo de conteúdo mercantil, a ser cumprida pelo órgão público, possibilita que ao acordo de vontade, fruto do vinculo bilateral, possa igualmente suceder o procedimento amigável como dirimente da eventual discrepancia no entendimento da latitude da obrigação do administrador.

Mais ainda se compatibiliza o juizo arbitral com atos de gestão de empresa estatal que se dedique à exploração de atividade econômica.

Maria D'Assunção C. MENEZELLO ${ }^{49}$ admite que, diante de interesses disponíveis, seja adotado o compromisso e chega a citar exemplos, como o da Lei de concessões de serviços públicos e o das licitações internacionais com recursos de instituições oficiais de fomento. São casos típicos em que a própria Administração direta - mesmo com personalidade de direito público - pode fazer uso de tal instrumento:

"Em nenhum momento, com a inclusão de cláusula de solução amigável de conflitos, olvida-se do princípio da indisponibilidade do interesse público. Muito ao contrário, ele se faz presente quando o "administrador público na iminência de um conflito contratual o resolve tendo por balizas os principios da economicidade, da razoabilidade, da motivação e principalmente da continuidade do serviço público', que vem a ser: resolver motivadamente o problema contratual da maneira mais econômica, sem deixar que os serviços públicos prestados à comunidade tenham qualquer solução." (n/grifo)

No Curso se Direito Administrativo ${ }^{50}$ tem-se repetidamente sustentado a obsolescência do então chamado princípio da supremacia do interesse público, que formulado com tal abstração e abrangência, como interesse próprio da pessoa estatal, externo e contraposto aos das pessoas, servia como instrumento de opressão e de

48 BARROSO, Luís Roberto. Sociedade de economia mista prestadora de serviço público. Cláusula arbitral inserida em contrato administrativo sem prévia autorização legal. Invalidade. Temas de direito constitucional. Rio de Janeiro: Renovar, 2003, tomo II, pp. 629 e 630.

49 MENEZELLO, Maria D'Assunção C. O conciliador/mediador e a árbitro nos contratos administrativos. Boletim de Direito Administrativo. São Paulo, ano XIIl, nº 12, dez, 1997, pp. 825-829. 50 MOREIRA NETO, Diogo de Figueiredo. Curso de Direito Administrativo. 13. ed. Rio de Janeiro, Forense, 2003 (v. p. 124). 
arbítrio da autoridade. Com o advento das Constituições instituidoras do Estado Democrático, os valores da pessoa humana foram reentronizados como os que realmente são supremos. ${ }^{51}$

\subsubsection{A admissibilidade do uso da arbitragem pela Administração Püblica}

Antes mesmo de concluir pela admissibilidade do uso da arbitragem por entes estatais, vale a pena citar entendimento de Eduardo Silva ROMERO ${ }^{52}$ :

Diante de uma exceção de falta de capacidade para recorrer à arbitragem suscitada por uma parte estatal, os árbitros internacionais, e notadamente aqueles agem sob a égide da CCl, não hesitam mais em afirmar que tal parte não poderia se furtar legitimamente das obrigações decorrentes de uma convenção de arbitragem com a qual consentiu livremente. Para apoiar essa posição, que é hoje bem firmada na jurisprudência arbitral, os árbitros CCI propuseram dois fundamentos: a ordem pública internacional e a boa fé.

\section{(...)}

Nos paises do Mercosul, e notadamente no Brasil e na Argentina, a arbitrabilidade subjetiva se vê limitada pela noção de contrato administrativo. Nesses países, o Estado e suas emanaçōes não têm a aptidão para celebrar convenção de arbitragem nos contratos administrativos. Por outro lado, no Brasil e na Argentina, as pessoas jurídicas de direito público atuando na qualidade de operadores privados podem incluir uma cláusula compromissóría nos contratos ditos de 'jure gestionis', ou seja, nos contratos de direito privado da administração. (n/grifo)

Em artigo específico sobre o tema ${ }^{53}$. recolheu-se a afirmação da tese vitoriosa no Supremo Tribunal Federal ao examinar o então momentoso caso da Organização Lage, em que a decisão do juízo arbitral instituído para dirimir litígio entre a União e herdeiros de Henrique Lage, acabou sendo objeto de admirável e paradigmática apreciação naquela Corte.

51 Colha-se do texto aludido a seguinte passagem que sintetiza a nova postura do Direito Público: "Essa busca de uma Constituiçāo administrativa. que perca seu ranço absolutista e autoritário e seja plenamente liberal e democrática, que assegure o primado do indivíduo e da sociedade, que garanta suas respectivas opções e que afirme a sua instrumentalidade política, significa, segundo Umberto ALLEGRETTI, um dos mais precisos expositores do fenômeno. 'que a administração deve atuar a serviço dos cidadãos, com ofim de promover as condiçóes de exercicio de seus direitos'. Eis, em poucas palavras, um conceito que revoluciona e altera profundamente os assentos tradicionais da Disciplina e. em consequiência. o próprio enfoque em que deva ser estudada (...)". MOREIRA NETO, Diogo de Figuciredo. Curso de Direito Administrativo. 13. ed. Rio de Janeiro, Forense, 2003, p. 125).

52 ROMERO, Eduardo Silva. A Arbitragem da Câmara de Comércio Internacional (CCl) e os Contratos de Estado. Revista de Direito Bancário, do Mercado de Capitais e da Arbitragem. São Paulo, a. 6. jan/mar, 2003, pp. 260-262.

53 MOREIRA NETO, Diogo de Figueiredo. RDA n 109, p. 81/90, jul/set 1997. 
Em primeiro grau, a pretensão dos herdeiros em sustentar a juridicidade da arbitragem havia sido acolhida e, em grau recursal, perante o antigo Tribunal Federal de Recursos, foi integralmente mantida, tendo o seu Relator, o Ministro Godoy ILHA $^{54}$, examinado em profundidade a questão doutrinária e sintetizado em sua Ementa as duas principais conclusões de fundo:

"Juizo Arbitral - Na tradição de nosso direito, o instituto do Juizo Arbitral sempre foi admitido e consagrado, até mesmo nas causas contra a Fazenda. Pensar de modo contrário é restringir a autonomia contratual do Estado. que, como pessoa 'sui júris', pode prevenir o litígio pela via do pacto de compromisso, salvo nas relaçóes em que age como Poder Público, por insusceptiveis de transação."

"Natureza consensual do pacto de compromisso - O pacto de compromisso, sendo de natureza puramente consensual, não constitui foro privilegiado, nem tribunal de exceção, ainda que regulado por lei específica."

Na precisa observação de seu primeiro comentarista, José Carlos de MAGALHÃES ${ }^{55}$, dois são os tópicos da Ementa que "fixam admiravelmente os contornos da arbitragem" ( $\mathrm{s} / \mathrm{c})$ ao reconhecerem:

$1^{\circ}$ - o seu caráter consensual $\mathrm{e}$

$2^{\circ}$ - a capacidade de o Estado brasileiro comprometer-se, "salvo na relações em que age como Poder Público, insusceptiveis, de transação. 56

Não tendo sido admitido recurso extraordinário contra esse Acórdão, tampouco prosperou o agravo de instrumento interposto pela União, registrando-se outra memorável decisão sobre o Estado e o instituto da arbitragem, desta feita, do Supremo Tribunal Federal, com duas singularidades dignas de registro histórico: o haver aluado como Relator o ilustre administrativista Bilac PINTO e o haver dado Parecer ${ }^{57}$ sobre o tema, constante do processo, o não menos ilustre administrativista Castro NUNES.

Esse Acórdão, que merece ser lido na íntegra por quantos pretendam aprofundar-se sobre a questão da arbitragem no Brasil, põe em evidência dois pontos importantes que se tornaram clássicos:

54 Agravo de Instrumento $n^{\circ}$ 52.181-GB, in RTJ, vol. 68, p. 382.

55 MAGALHÃES, José Carlos de e BAPTISTA, Luiz Olavo. Arbitragem Comercial. In: Do Estado na Arbitragem Privada. Rio de Janeiro: Freitas Bastos, 1986, p. 70.

56 Op. cit. p.78.

57 No referido Parecer, da lavra de NUNES, Castro, esposado por PINTO, Bilac: aludem-se aos pronunciamentos, dentre outros, de LAFAYETTE, do Visconde de OURO PRETO e de COSTA E SILVA, reconhecendo a extensão aqui defendida do instituto da arbitragem, então disciplinado pelo Decreto $n^{\circ} 3.900$, de 27 de julho de 1867, às causas da Fazenda Nacional (Acórdão no Agravo do Instrumento $n^{\circ}$ 52.181-GB, in Revista Trimestral de Jurisprudência, Vol. 68, abril de 1974, p. 391). 
$1^{\circ}$ a tradição doutrinária brasileira, assentada desde o Império, em aceitar a arbitragem nas causas da Fazenda, e

$2^{\circ}$ a impossibilidade de interdição do juízo arbitral nessas causas, pois isso importaria numa restrição à autonomia contratual do Estado ${ }^{58}$.

Esses brilhantes leading cases, expostos no referido artigo de 1997, cinco anos mais voltaram merecidamente a ser examinados na doutrina brasileira, desta feita com a chancela de seu Mestre maior, Caio TÁCITO ${ }^{59}$, que assim se expressou:

"O Supremo Tribunal Federal enfrentou, porém, em outros termos, a questão da viabilidade do juizo arbitral no tocante a direitos patrimoniais oponiveis ao Estado.

Longa demanda judicial conclui-se em julgamento da Corte Suprema, proferido em 14 de novembro de 1973, no Agravo de Instrumento $n^{\circ} 52181$ (Revista Trimestral de Jurisprudência - vol. 88, p. 382 e ss)

Empresas da Organização Lage reivindicavam direito a receber indenizações decorrentes do torpedeamento de navios durante a Segunda Guerra Mundial, que integravam o acervo incorporado ao Patrimônio Nacional.

O Decreto- lei $n^{\circ}$ 952, de 26 de julho de 1946, admitia que a transferência de valores poderia ser determinada mediante juizo arbitral, cujo laudo foi, porém impugnado pela Procuradoria Geral da Fazenda Nacional, aprovado pelo Governo. sob o fundamento da inconstitucionalidade da lei autorizativa da arbitragem.

'Confirmando decisão do Tribunal Federal de Recursos que, pelo voto do Ministro Godoy Ilha, afirmara a admissibilidade do juizo arbitral, o Supremo Tribunal federal, em decisão plenária unânime adotou o voto do Ministro Bilac Pinto, ratificado em voto do Ministro Rodrigues Alkmin, no sentido da constitucionalidade da instituição, no caso, do juízo arbitral.'

Lembrou o relator que, desde o Império, em autorizados pronunciamentos, entre outros, de Lafayette. do Visconde de Ouro Preto e do Conselheiro Silva Costa, era acolhido o instituto de arbitragem em causas da Fazenda Nacional. Nem a Carta de 1937, nem a Constituição de 1967/69 então vigente vedavam, na hipótese, a instituição do juizo arbitral, que não violava ao princípio da competência do Poder Judiciário."

58 Idem, ibidem.

59 TÁCITO, Caio. Temas de direito público. Rio de Janeiro: Renovar, 2002, v. 3, pp. 83-88. 
E, prosseguindo ${ }^{60}$, com o exame do tema no direito positivo vigente:

"A questão do cabimento do juizo arbitral, em matéria pertinente a contratos administrativos, assumiu aspecto novo com o advento da Lei $n^{\circ} 8.987 / 95$, que dispóe sobre concessões e permissões de serviços e obras públicas.

Nos termos do respectivo art. 23, inscrevem-se entre as cláusulas essenciais do contrato de concessão de serviço público, as relativas ao "foro e ao modo amigável de solução de divergências contratuais" (Item XV).

O Estado do Rio de Janeiro, em preceito pioneiro, já consagrava no art. $5^{\circ}, \$ 2^{\circ}$, da Lei Estadual $n^{\circ} 1.481$, de 21 de julho de 1989, a previsão expressa de juízo arbitral como solução consensual de controvérsias administrativas.

Em igual sentido, a lei paulista $n^{\circ} 7.535$, de 8 de maio de 1982, prevê a admissão contratual da solução amigável de controvérsias (art. $8^{\circ}, \mathrm{XXI)."}$

Tem sido essa, pois, a linha dominante: sempre que puder contratar - o que importa em existência de disponibilidade atinente a interesse e direitos patrimoniais - poderá a Administração (direta ou indireta) convencionar cláusula de arbitragem, sem que isso importe disposição do interesse público, mas, muito ao contrário, um método para satisfazê-lo de modo mais célere, mais técnico, com custos menores e, sobretudo, com as vantagens da consensualidade.

\subsubsection{A admissibilidade da arbitragem na Administração Pública Empresarial}

Mas ainda que restassem dúvidas quanto à correta adoção da arbitragem para dirimir conflitos no âmbito da Administração direta e autárquica, muito mais evidente é a sua viabilidade quando se trate da Administração Pública Indireta Paraestatal, de cunho empresarial, quando em jogo interesses disponiveis. Neste caso, mais que legítimo, o uso da arbitragem é recomendável, posto que, como acima se indicou, privilegia uma forma célere de atendimento do interesse público, o que, afinal, vem a ser uma forma de melhor atendê-lo.

Essa peculiaridade já estava salientada em Themístocles CAVALCANTI ${ }^{61}$ :

"A administração realiza muito melhor os seus fins e a sua tarefa, convocando as partes que com ela contratarem, a resolver as controvérsias de direito e de fato perante o juizo arbitral, do que denegando o direito das

60 TÁCITO, Caio. Op. cit., pp. 83-88.

61 In: GRAU. Eros Roberto. Da arbitragem de litígios envolvendo sociedades de economia mista e a interpretação de cláusula compromissória. Revista de Direito Bancário. do Mercado de Capitais e da Arbitragem. São Patulo, a. S, out/dez, 2002, pp. 398, 399 e 402 - 404. 
partes, remetendo-as ao juízo ordinário ou prolongando o processo administrativo, com diligências intermináveis, sem um órgão diretamente responsável pela instrução do processo."

Beat Walter RECHSTEINER ${ }^{62}$ é outro que sufraga esse entendimento:

"No Brasil, aceita-se a arbitragem como o meio jurídico válido para o Estado e suas empresas estatais, a fim de solucionar litígios com particulares, inobstante a sede do tribunal arbitral esteja situada no estrangeiro", (n/grifo)

Na mesma linha, sustenta Arnold WALD ${ }^{63}$ :

"Efetivamente, nos tiltimos vinte anos, por diversas vezes, as sociedades brasileiras de economia mista submeteram os seus litígios aos tribunais arbitrais, como ocorreu em relação a Furnas e a subsidiárias diretas ou indiretas da Petrobrás. Com a recente legislação e regulamentação tratando de modo específico da arbitragem no campo das concessões, parecia não haver mais razões para discutir a utilização da arbitragem no setor:

(...)

A aceitação por empresa mista da decisão arbitrai constitui pois um exemplo que merece ser salientado. Sempre consideramos, desde o inicio da metade do século passado, que a sociedade de economia mista devia submeter-se, nas suas relações com terceiros, às normas que incidem sobre todas as demais sociedades comerciais, sem qualquer privilégio. Trata-se, aliás, de uma das importantes diferenças entre a sociedade de economia mista, de um lado, e as autarquias, de outro. O entendimento doutrinário e jurisprudencial é, atualmente, de caráter constitucional, na medida em que o art 173. \$1 $1^{\circ}, 1$, da CF reconhece a sujeição da empresa pública, da sociedade de economia mista e de suas subsidiárias ao regime jurídico das empresas privadas, inclusive quanto aos direitos e obrigações civis, comerciais, trabalhistas e tributárias.' Assim sendo, não nos parece haver dúvida quanto à validade e eficácia da cláusula compromissória convencionada por sociedades de economia mista."

Em obra coletiva em que o tema recebeu tratamento específico, Arnoldo WALD, Athos GUSMÃO CARNEIRO, Miguel Tostes de ALENCAR e Ruy Janoni DOURADO $^{64}$ lecionam:

62 RECHSTEINER, Beat Walter. Arbitragem Privada Internacional no Brasil. São Paulo: Revista dos Tribunais, 1997, p. 138.

63 WALD, Arnold. A arbitragem e as sociedades de economia mista. Revista de direito bancário, do mercado de capitais e da arbitragem. São Paulo, ia. 6 jan/mar. 2003, pp. 377 e 378.

64 WALD. Arnoldo. CARNEIRO, Athos Gusmão. ALENCAR Miguel Tostes de. DOURADO, Ruy Janoni. Da validade de convenção de arbitragem pactuada por sociedade de economia mista. 
"Decerto, foram as sociedades de economia mista colocadas em situação de igualdade em relação às empresas privadas nos seus misteres negociais, evidenciando-se a inexistência de quaisquer restrições quanto à possibilidade de celebrar convenções de arbitragem para a solução de conflitos de interesses, tal como as suas congêneres privadas estampara tanto legitimadas." (...)

Deveras, não se podem respigar em leis anteriores ao advento da arbitragem óbices para a sua atuação na sociedade de economia mista, que acompanha, por força de comando constitucional, a disciplina negocial das empresas privadas. É de pacífica regra de hermenêutica deverem as restrições ser interpretadas restritivamente, máximo no plano da autonomia da vontade. A presença do Estado no bojo de tais sociedades não lhes atribui o cariz de Administração Pública, a ponto de empecer o regular desempenho de suas atividades, que carecem de meio expedito de solução de litígios."

Recorde-se que as empresas públicas e as sociedades de economia mista, por força do art. $173, \S 1^{\circ}$, II, da Constituição da República, se submetem ao mesmo regime jurídico das empresas do setor privado (ex: art. $5 .^{\circ}$, inciso III, do Decreto-lei $n^{\circ} 200 / 67$ e Lei $n^{\circ} 6.404 / 76$, art. 235), daí não celebrarem contratos administrativos, regidos pelo direito público, mas contratos de direito privado, sob regência privada.

Tal é o caso típico da compra e venda de energia.

\section{O principio da boa fé nos contratos e a efetividade de suas cláusulas.}

Hoje é reconhecido nos escritos especializados que nos contratos dá-se um compartilhamento de riscos entre os contratantes, e mais, que essa peculiaridade solidária, muito mais presente nos contratos que exigem grandes investimentos e têm sua implementação desenvolvida em longo prazo, gera profundas consequiências econômicas e jurídicas. Com efeito, é em função desse risco que cada parte confia que a outra dará cumprimento ao que foi pactuado.

Assim, acima e além dos interesses próprios de cada um dos contratantes, paira um interesse comum, a reger-lhes as relações contratuais de um modo bem mais amplo. Ele deriva da finalidade comum, traduzida no interesse solidário dos contratantes em levarem a cabo a execução do objeto contratual, até como forma de assegurar a viabilização dos seus interesses próprios.

É essa solidariedade entre as partes que, assim gerada, as compele racional e razoavelmente a buscar agir cooperativa e não antagonicamente, para superar obstáculos.

Revista de Direito Bancário, do Mercado de Capitais e da Arbitragem. São Paulo, a. 5, out/dez, 2002, pp. 409-419. 
É esta, portanto, a idéia-força que justifica o princípio da boa-fé objetiva, e que obriga as partes a empreenderem seus melhores esforços para que ambas consigam cumprir o acordado, de modo a concluí-lo a bom termo.

Examinando o aspecto ético subjacente, Heloísa CARPENA afirma ${ }^{65}$ :

"O elemento moral das obrigações é dado principalmente pela boa fé objetiva, cuja incidência, au reduzir o campo de aplicação do princípio da autonomia privada, vem legitimar o vínculo contratual en contemplação dos efeitos sociais que ele produz e não apenas em atenção aos interesses egoísticos das partes contraentes." (n/grifo). RENZ:

Mário de Camargo SOBRINHO ${ }^{66}$ afirma, considerando o legado de Karl LA-

"a boa-fé contratual cabe dentro da objetiva. A boa fé contratual, especificamente, traduz-se de cada parte agir de forma a não defraudar a confiança da contraparte. Impõe-se em primeiro lugar ao devedor e ao credor, mas, como adverte Larenz, alcança outros participantes da relação jurídica". (Karl LARENZ, Derecho de Obligaciones. Trad. Madrid, Editorial Revista de Derecho Privado, 1958, v. 1,p. 148).

E, em se valendo dos ensinamentos de FERNANDO NORONHA, explana, ainda, que essa boa fé objetiva é também designada de boa fé lealdade, como expressão que enfatiza o dever de agir que impende sobre cada uma das partes. Outra designação, que também lhe é dada, é a de boa fé confiança, que realça a finalidade do princípio, que se volta à tutela das legítimas expectativas da contraparte, para garantia da estabilidade e segurança das transações.

Em síntese, na boa-fé objetiva, uma parte tem como regra de conduta um dever de agir de acordo com determinados padrões sociais, de correção de lisura, de honestidade, para não frustrar a confiança da outra parte.

Daí porque a solidariedade pactuada e devida nos contratos demanda das partes um comportamento ajustado com vistas ao atingimento do interesse comum, sobressaindo, nessa linha, esta clara lição de Cláudia Lima MARQUES ${ }^{67}$ :

“(...) atuação refletida, uma atuação refletindo, pensando no outro, no parceiro contratual, respeitando-o, respeitando seus interesses legítimos, suas expectativas razoáveis, seus direitos, agindo com lealdade, sem abuso,

65 CARPENA, Heloísa. Abuso do Direito nos Contratos de Consumo. Rio de Janeiro: Renovar, 2001. p. 90.

66 CAMARGO SOBRINHO, Mário de. Contrato de Adesão e necessidade de uma legislação específica. Campinas: São Paulo. Interiex Informações Jurídicas, 2000. p. 43.

67 MARQUES, Cláudia Lima. Contratos no Código de Defesa do Consumidor. O novo regime das relações contranuais. São Paulo: Revista dos Tribunais, 1992, pp. 79 e 80. 
sem obstrução, sem causar lesão ou desvantagem excessiva, cooperando para atingir o bom fim das obrigações' o cumprimento do objetivo contratual e a realização dos interesses das partes." (n/grifo).

Com efeito, a solidariedade entre contratantes se torna mais evidente em pactos como este, que aqui se analisa, no qual, como dito, prevalece a idéia de parceria e de colaboração.

Assim é que, sem sombra de dúvida, a idéia central de confiança mais ainda se reforça quando em jogo uma entidade da Administração Pública, eis que, a contratante autorizatária é o administrado - que, mais do que um contratante ordinário, tornou-se um parceiro, nesta concepção solidária do novo Direito Administrativo, e tem, assim, o direito subjetivo público substantivo de esperar que os órgãos e entidades da Administração Pública sejam os primeiros responsáveis pelo atendimento da saúde econômica do contratado, bem como pela preservação dos seus direitos. ${ }^{68}$

Trata-se, na verdade, de pressupostos do próprio princípio da segurança jurídica.

Ocorre que, no caso em exame, caracterizando um verdadeiro desvio de finalidade, o interesse da contratante estatal passou a ser, apenas, o de desfazer o contrato, isso sem que nenhum descumprimento de seus termos pudesse ser imputado à contratada, pretextando, para tanto, essa "nulidade" de cláusula compromissória por ela firmada. Todos esses conceitos restam inegavelmente violados pelo comportamento imperial da sociedade de economia mista assumido neste caso concreto, arrogando-se titular de uma prerrogativa típica do Poder Público para extinguir unilateralmente um contrato. Em suma, e tão grave como se pode observar: nenhum interesse público se vislumbra e resta atendido com tal atitude e em tal linha de argumentação da sociedade de economia mista.

Com efeito, mergulhando agora nos fatos, a mudança inopinada e tardia de orientação legal assumida por essa paraestatal estadual, afronta o princípio da segurança jurídica, já consagrado em lei federal. ${ }^{69}$

Mais do que o particular, a Administração, seja ela a Direta ou a Indireta, deve zelar pêlos princípios acima, exatamente em razão das prerrogativas de supraordinação.

No caso de uma empresa estatal, dado o interesse público que existe na prestação de serviços públicos, que a torna legítimo instrumento de ação estatal, robustece-se o dever de preservar a segurança, que legitimamente se espera das relações em que

68 A emergência da concepção pós-moderna dos direitos subjetivos públicos foi resultado da "constitucionalização do direito", uma expressão de FAVOUREU, Louis, que tende à unificação do Direito na superestrutura constitucional, o que dilui, senão que elimina, a summa divisio ( $v$. a recentíssima obra de FOULQUIER, Nobbert. Lês droits publics subjectifs des administres. Paris: Dalloz, 2003, p. 445, detentora do Prêmio Henri Texier, da Academia de Ciências Morais e Políticas da França).

69 Cf. art. $2^{\circ}$, caput, da Lei $n^{\circ} 9.784$, de 29 de janciro de 1999. 
figure, e a proteção aos contratados de boa fé, impedindo que venham a sofrer direta e isoladamente os efeitos da mudança repentina de eventual orientação e de comportamento negocial da empresa estatal.

Por esses fundamentos é que não se pode admitir modificação superveniente e inesperada das relações jurídicas válidas e legitimamente constituídas.

Como se espelha com clareza na doutrina de J. J. Gomes CANOTILHO ${ }^{70}$ :

"O homem necessita de 'segurança' para conduzir, planificar e conformar autônoma e responsavelmente a sua vida. Por isso, desde cedo se consideravam os princípios da 'segurança jurídica' e da 'proteção da confiança como elementos constitutivos do Estado de direito. Estes dois princípios segurança jurídica e proteção da confiança - andam estreitamente associados a ponto de alguns autores considerarem o princípio da proteção de confiança com um subprincípio ou como uma dimensão especifica da segurança jurídica. Em geral, considera-se que a 'segurança jurídica' está conexionada com elementos objetivos da ordem juridica - garantia de estabilidade jurídica, segurança de orientação e realização do direito enquanto a 'proteção da confiança' se prende mais com as componentes subjetivas da segurança, designadamente a calculabilidade e previsibilidade dos indivíduos em relação aos efeitos jurídicos dos atos dos poderes públicos. A segurança e a proteção da confiança exigem, no fundo: (1) fiabilidade, clareza, racionalidade e transparência dos atos do poder; (2) de forma que em relação a eles o cidadão veja garantida a segurança nas suas disposições pessoais e nos efeitos juridicos dos seus próprios atos. Deduz-se já que os postulados da segurança jurídica e da proteção da confiança são exigiveis perante qualquer ato de qualquer poder - legislativo, executivo e judicial. (...) (3) em relação a atos da administração tendencial estabilidade dos casos decididos através de atos administrativos constitutivos de direitos." (n/grifo)

São premissas que se encontram em estrita sintonia com o atual estado doutrinário da proteção da boa fé do administrado, consubstanciado no 'princípio da confiança legítima' (Vertrauenschutz) tal como emergiu da sentença pioneira alemã (OVG Berlim, 14 de novembro de 1956), bem como da obra clássica de MERUSI ${ }^{71}$.

Para Hartmut MAURER ${ }^{72}$, essa proteção decorre do próprio status de cidadania, construído a partir do conceito de Estado Democrático de Direito:

"A proteção à confiança parte da perspectiva do 'cidadão'. Ela exige a proteşào da confiança do cidadão que contou, e dispôs em conformidade

70 CANOTIl.ho, J. J. Gomes. Direito Constinucional e Teoria da Constinuição. 3. ed. Coimbra: Almedina, 1998, p. 252.

71 MERUSI. L'affidamento del Citadino. Milão: Giufïrè, 1970.

72 MAURER. Hartmut. Elementos de Direito Administranivo Alemão. Rio de Janeiro: Sérgio Antônio Fabris, 2001, p. 68, tradução de Dr. HECK, Luís Afonso. 
com isso, com a existência de determinadas regulações estatais e outras medidas estatais. Ela visa à conservação de estados de posse uma vez obtidos e dirige-se contra as modificações jurídicas posteriores."

Destaque-se, ainda, a doutrina de Jesus Gonzalez PÉREZ ${ }^{73}$, que apresenta como requisito para a aplicação do princípio da confiança legítima que o ato praticado pela Administração Pública seja suficientemente conclusivo para provocar no interessado a certeza de que a Administração atuou corretamente, que o próprio administrado está se comportando licitamente, bem como a convicção no sentido de que as suas expectativas como interessado são razoáveis.

Também René CHAPUS já vê o princípio da confiança legítima de há muito tempo agasalhado pela jurisprudência francesa, conforme aresto de 1929, do Conselho de Estado ${ }^{74}$, que reconheceu a responsabilidade da Administração ao alterar bruscamente seu comportamento, ainda que com bases legais, "iludindo a confiança que o administrado podia manter legitimamente quanto à estabilidade da situação" ${ }^{75}$, bem como em recente decisão do Tribunal Administrativo de Estrasburgo, no qual se afirma claramente o princípio de que a Administração deve velar para que não modifique nem a regulamentação em vigor nem seu comportamento de modo inopinado, sempre que o caráter brusco dessa modificação não se faça necessário aos interesses públicos. ${ }^{76}$

$\mathrm{Na}$ doutrina brasileira, Luís Roberto BARROSO ${ }^{77}$, ensina que é dever do "Estado comportar-se diante do administrado de modo a não surpreendê-lo com decisões imprevisiveis, frustrando expectativas legitimas."

Como se observa, não apenas os direitos, mas até as legítimas expectativas merecem a proteção da ordem jurídica. Daí o seu acolhimento, com o devido destaque, no art. 54, caput, da já referida Lei $n^{\circ} 9.784$ de 29 de janeiro de 1999. E não por outra razão, se trata de um Diploma que não só regula o processo administrativo federal como assenta os fundamentos de toda essa categoria processual a nível nacional, consoante se pode comodamente retirar do art. 22, I, da Constituição.

Nesse contexto, deve-se resguardar, além da segurança jurídica e solidez dos negócios em que o Estado (Administração Püblica Indireta) seja parte, os interesses de todos aqueles envolvidos de boa-fé que, em razão do comportamento negocial

73 PÉREZ, Jesus Gonzalez. El Principio General de La Buena Fé e el Derecho Administrativo. 3. ed. Madri: Civitas, 1999, p. 55 (livre tradução).

74 Cie. dês Mines de Siguiri, p. 1022. S 1930, coin nota de BONNARD, Roger "a propósito da retirada súbita de uma autorização, que o Conselho analisa como realizada 'em condições abusivas"”.

75 CHAPUS, René. Droit Administratif General, 13. ed. Paris: Montchrestien. 1999, tomo I, p. 97.

76 CHAPUS. René. Op. cit. p. 98.

77 BARROSO, Luís Roberto. Temas de Direito Constitucional. São Paulo: Renovar, 2001, p. 336. Parecer: "Direito Adquirido, Confisco, Isonomia e Boa Fé: Planos Econônicos, FGTS e expurgos inflacionários." 
adotado pela Administração Pública, conduzem e consolidam seus respectivos negócios jurídicos.

Isso posto, o rompimento de uma relação bilateral negociada, já estabilizada entre as partes e que prosseguia em fase de execução consensual, resulta, nessas circunstâncias, em uma flagrante violação aos princípios da segurança jurídica e da legítima boa fé dos contratantes, posto que transacionaram de forma legal.

Efetivamente, como é sabido, contratos dessa natureza envolvem obrigações complexas, sujeitas, tantas vezes, às condições de mercado nacionais e internacionais, além de estarem dependentes de outras variáveis, imprevisíveis no momento em que o contrato é celebrado.

Eis porque não poderá gerar contra a autorizatária os catastróficos efeitos jurídicos pretendidos pela sociedade de economia mista, essa sua inopinada e repentina mudança de comportamento, tomada inaudita altera pars, de modo imperial, depois de concordar com o compromisso arbitral livremente firmado.

De fato, tratando-se de pessoa jurídica de direito privado, em contrato regido igualmente pelo direito privado, a sociedade de economia mista não pode pretender que contratantes de boa fé sejam obrigados a suportar a inesperada negação de regras preexistentes de um acordo cuidadosa, demorada e elaboradamente celebrado por empresas de porte e respeitáveis, não se aproveitando nem mesmo a desculpa de se tratar de uma pequena empresa, despreparada ou de uma negociação feita de afogadilho, se é que argumentos desse jaez poderiam ser de proveito para eximi-la do dever de cumprir o pactuado.

É indubitável que essa rigorosa fidelidade à execução e a preservação das tratativas onerosas por parte da autorizatária hão de ser tuteladas na aplicação do Direito, não cabendo o repentino rompimento unilateral do contrato, pois, conforme ensina Caio Mário da Silva PEREIRA ${ }^{78}$ :

"É preciso ter em vista que os efeitos da resilição unilateral diferem dos da bilateral. Esta importa na extinção do contrato e de suas conseqüências, tendo por limites as conveniências das partes e os direitos de terceiros. Aquela, não obstante gerar a extinção da relação contratual, compadece-se com a extensão de efeitos do contrato atingido".

“...o parágrafo tínico do art. 473 do Código determina que 'se, dada a natureza do contrato, uma das partes houver feito investimentos consideráveis para a sua execução, a denúncia unilateral só produzirá efeito depois de transcorrido prazo compativel com a natureza e o vulto dos investimentos'. Esta é uma novidade do Código de 2002. 'O legislador poderia ter determinado apenas o pagamento das perdas e danos sofridas pela parte que teve prejuizos com a dissolução unilateral do contrato'. Preferiu the atribuir uma tutela específica, transformando o contrato que por natureza poderia ser extinto por vontade de uma das partes, em um contrato comum,

78 PEREIRA, Caio Mário da Silva. Instimiçōes de Direito Civil. 11. ed., vol. III. Rio de Janeiro: Forense. 2003, pp. 153 - 156, 165 e 571. 
valendo essa nova regra pelo prazo compativel com a natureza e o vulto dos investimentos. 'Caberá ao juiz determinar, com a ajuda da perícia técnica se necessário, o prazo em que fica suspenso o direito da parte de resilir unilateralmente o contrato sem qualquer motivação especifica. $O$ critério legal é o de proporcionar à parte prejudicada pela resilição unilateral a obtenção do objetivo previsto no contrato, de acordo com a natureza do contrato e dos investimentos realizados'."

"Admitindo-se que os contratantes, ao celebrarem a avença, tiveram em vista o ambiente econômico contemporâneo, e previram razoavelmente para o futuro, o contrato tem de ser cumprido, ainda que não proporcione às partes o beneficio esperado. Mas, se tiver ocorrido modificação profundas nas condições objetivas coetâneas da execução, em relação às envolventes da celebração, imprevisiveis em tal momento, e geradoras de onerosidade excessivas para um dos contratantes, ao mesmo passo que para o outro proporciona lucro desarrazoado..."

"Dai também a conviç̧ão de que a filosofia contratualista enuncia com verdade apodíctica: sendo inspirado no acordo das vontades, e sendo expressão do querer dos contratantes, não se poderia admitir que as vontades livres pudessem estipular uma avença que atentasse contra o principio imanente de justiça. E, então, o jurista de século XIX afirmava, e o do começo do século XX repetia: "Quem diz contratual diz justo", (n/grifo).

A preocupação, que aqui se enfatiza, com o grau de complexidade da atividade contratada e com os investimentos já realizados tampouco passou desapercebida ao sempre lembrado Mestre Caio TÁCITO ${ }^{79}$, que utilizou um tropo bem figurativo:

"Em aeronáutica, quando o plano de vôo de uma aeronave ultrapassa determinada etapa de realizaçāo, torna-se inviável a alternativa de voltar ao ponto de partida, impondo-se o prosseguimento até o destino. Estará atingido o denominado ponto de não retomo (point of no return).

Similarmente, projetos de obras ou serviços, de alta complexidade, apresentam, quando se atinge grau avançado de execução, a impossibilidade de abandono da parte já contemplada, sem grave dano à sua viabilidade, ou irremediável lesão econômico-financeira." (n/grifo)

No caso, reconheça-se, por ser evidente, que a sociedade de economia mista pretende obter vantagem da própria torpeza: rompeu-se unilateralmente e com solércia a solidariedade finalística própria deste tipo de contratação, eis que a referida empresa estatal ignorou por completo as obrigações já assumidas pela autorizatária de produção independente de energia, não havendo como negar que a 'segurança

79 TÁCITO, Caio. Temas de direito público: (estudos e pareceres). Rio de Janciro: Renovar, 1997,v. 2, p. 1396. 
jurídica e a boa fé objetiva protegem, dentre outros princípios jurídicos, os negócios em geral. Daí a previsão de indenização mediante compra da usina construída para cumprir o contrato. Dada a natureza indenizatória sequer há que se falar em prévia licitação para a aquisição da usina.

6. A impossibilidade de afastamento judicial da aplicabilidade do compromisso arbitral

Firmado o compromisso entre partes capazes, torna-se ele obrigatório para ambos, sendo vedado ao Judiciário, negando vigência à lei federal, invadir tal esfera de autonomia, como afirma Aristóteles ATHENIENSE ${ }^{80}$ :

"Ao Judiciário não é permitido rever ou modificar a decisão concessiva da tutela emergencial proferida em juizo arbitral; ao juiz estatal cabe somente deferir a providência adotada no procedimento arbitral, a não ser que esta contenha algum vicio formal ou nulidade de ordem pública, que comporte o decreto de nulidade."

A cláusula compromissória permite à parte interessada em resolver a disputa tomar a iniciativa para a instauração da arbitragem, ficando a outra, uma vez feito o pedido, obrigada a aceitá-la, não havendo a possibilidade de opção entre as jurisdições arbitral e estatal. Portanto, um Tribunal Arbitral formar-se-á de acordo com o Regulamento de Arbitragem que haja sido escolhido na forma da convenção de arbitragem, sendo, a este respeito, as normas da $\mathrm{CCl}^{81}$ uma referência universalmente aceita.

\section{Conclusão}

A partir das premissas acima assentadas, se pode afirmar à guisa de conclusões:

$1^{\circ}$ - Os atos e contratos celebrados por empresas estatais, ainda que de direito privado, se submetem aos princípios que regem a Administração Pública, em espe-

80 ATHENIENSE, Aristóteles. As medidas coercitivas no juizo arbitral. Revista de direito bancário, do mercado de capitais e da arbitragem. São Paulo, a. 6, jan/mar, 2003, pp. $313-316$.

81 ROMERO, Eduardo Silva. A Arbitragem da Câmara de Comércio Internacional (CCI) e os Contratos de Estado. Revista de Direito Bancário, do Mercado de Capitais e da Arbitragem. São Paulo, a. 6, jan/mar, 2003, p. 289. Dita que: "numerosas pessoas jurídicas de direito público e seus co-contralantes privados estrangeiros já confiaram no sistema de arbitragem da CCI. As estatísticas da Corte Internacional de Arbitragem atestam tal fato: 67 dos 541 pedidos de arbitragem submetidos à Corte em 2000 envolveram uma ou diversas entidades públicas ou semi-públicas: dos 566 casos de arbitragem registrados em 2001, 49 envolveram partes estatais ou semi-puiblicas provenientes da Europa Central e do Leste, da Ásia do Sul e do Leste, da África Sub-Saariana e da América Latina. Parece. conseqüentemente, que a maioria das pessoas jurídicas de direito público participando de procedimentos arbitrais da $\mathrm{CCI}$ provêm de paises em vias de desenvolvi. mento". 
cial, os da segurança jurídica, da motivação, da proteção da boa fé, e da adoção da formalidade mitigada.

$2^{\circ}$ - Os contratos celebrados por empresas estatais, por força do disposto no art. 173, $\S 1^{\circ}$, II, da Constituição Federal, estão sujeitos a um regime híbrido que envolve a obediência às regras de direito privado, não podendo ser considerados como contratos administrativos, estando, pois, desautorizado o uso e a aplicação de cláusulas exorbitantes, que atribuam poderes e prerrogativas não exercitáveis pela parte contratada.

$3^{\circ}$ - A arbitragem é de adoção juridicamente viável pela Administração Pública, sempre que a questão envolver interesses disponíveis. A lei de arbitragem, já decidida como constitucional pelo Eg. STF, tem transformado o instituto ora analisado em verdadeira fórmula de efetividade da jurisdição, de modo a proporcionar aos administrados a rápida e eficaz onerosa solução dos conflitos de interesses, com atuação instrumental e adjetiva do Estado. A empresa estatal, na qualidade de sociedade de economia mista, submetida ao regime jurídico de direito privado, celebrando contratos regidos pelo direito privado, firmou, validamente, compromisso arbitral com a autorizatária; portanto, como partes capazes de pleno direito, ficam elas obrigadas ao juízo arbitral, por serem tais cláusulas juridicamente válidas.

$4^{\circ}$ - É nula e lesiva ao direito individual a decisão unilateral da estatal de denunciar de inopino e 'sem observância do devido processo legal' uma obrigação contratual de instrumento que vinha sendo cumprido e em função do qual a autorizatária, como contratada de boa-fé, vinha praticando todos os atos necessários à execução da sua obrigação.

$5^{\circ}$ - Se a contratante não mais tem interesse em manter o ajuste, deve reparar os prejuizos sofridos pela contratada, que. de boa lé, desenvolveu atividades, contratou pessoas, contraiu financiamentos e fez toda sorte de dispêndios previsíveis para o atendimento de prestação de natureza complexa para prover bens e serviços não imediatamente disponíveis no mercado. 


\section{Revista de Direito Administrativo}

Caio Tácito (organizador)

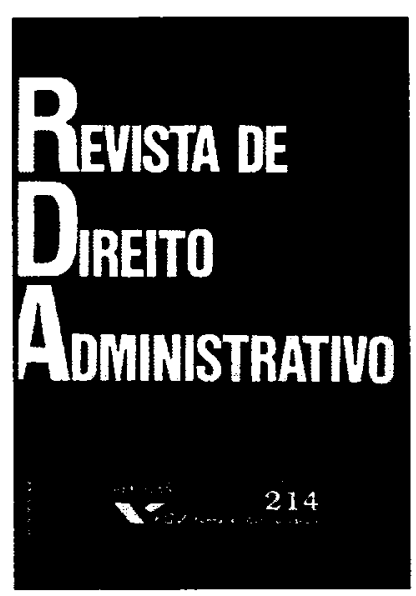

Com mais de meio século de publicação regular e ininterrupta, é a mais completa publicação no gênero. Em quatro números anuais oferece a mais completa e atualizada visão do Direito Administrativo brasileiro, no plano da doutrina e pareceres, da jurisprudência administrativa, judicial e do Tribunal de Contas da União, e da Legislação Federal. Na sua especialidade, divulga temas de Direito Constitucional, Tributário ou Processual que interessam à interpretação e aplicação dos princípios e normas que regulam a atividade da Administração Pública Direta e Indireta.

Brochura

Form. 16x23

\section{Revista de Direito Administrativo \\ Seleção Histórica}

Vários autores

A presente coletânea reúne trabalhos publicados nos 150 primeiros números da Revista de Direito Administrativo, os quais, pela densidade do conteúdo, permanecem válidos como subsídios à doutrina do Direito Público. A seleção, se não esgota o lastro do passado, evidencia a perenidade de contribuições antigas e propicia aos leitores de agora uma expressiva amostra da presença de autores falecidos que deixaram marca na história da ciência jurídica nacional.

Ref. 0102

Form. 16x23

Brochura 1996
467 págs.

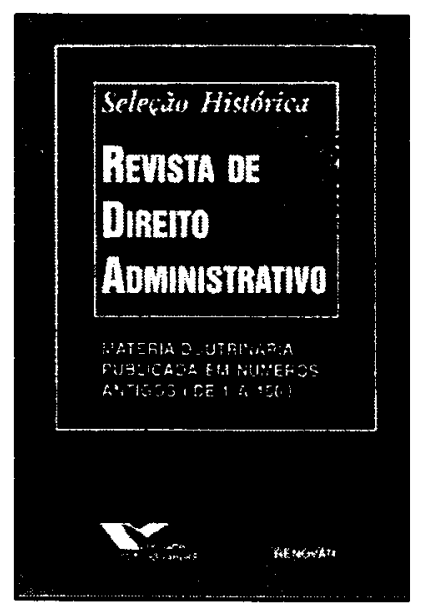

